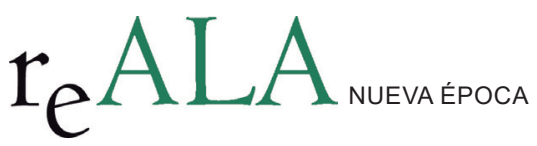

REALA, Nueva Época - N. ${ }^{\circ}$, enero-junio 2016 - ISSN: 1989-8975

DOI: http://dx.doi.org/10.24965/reala.voi5.10350

\author{
Ana María De la Encarnación \\ Universidad de Valencia \\ Ana.Maria.Encarnacion@uv.es
}

\title{
El alojamiento colaborativo: Viviendas de uso turístico y plataformas virtuales
}

\section{Resumen}

La llamada economía colaborativa, fenómeno innovador de alcance global y transversal, supone la apuesta por una alternativa a las prácticas hasta ahora conocidas en nuestra sociedad de consumo. Esta idea de la economía colaborativa ha tenido una gran repercusión más allá de su incidencia en los mercados de servicios y bienes, afectando de forma directa al sector del alojamiento turístico. De hecho, se han generalizado de forma extraordinaria diferentes alternativas al alojamiento vacacional más tradicional, mediante plataformas virtuales que ofrecen viviendas privadas para su uso turístico a precios competitivos y prometen experiencias más cercanas a la convivencia vecinal que turística. Analizaremos estas nuevas posibilidades que se ofertan y su incidencia en nuestro ordenamiento jurídico.

Palabras clave

Economía colaborativa, alojamiento turístico, alojamiento colaborativo, Airbnb, viviendas turísticas, plataformas virtuales, arrendamientos vivienda turística.

\section{Peer-to-peer accommodation and home-sharing platforms}

\section{Abstract}

The so-called collaborative consumption is an innovative global phenomenon that entails an alternative to widely used consumer-society practices. The sharing-economy has had a major impact beyond the markets to goods and services, directly affecting the hotel industry, tourism and accommodation. These alternatives to more traditional vacation rental are, in fact, wide-spreading thanks to the home-sharing platforms offering private homes for tourist use at competitive prices, assuring neighbourhood experiences -your home, everywhere-. In this paper we analyse all these new possibilities of sharing-accommodation and its impact upon the Spanish legal system.

\section{Keywords}

Sharing-economy, collaborative consumption, peer-to-peer economy, peer-to-peer accommodation, Airbnb, online platforms, peer-to-peer platforms, short-term accommodation, short-term rentals. 
1. Introducción. 2. A vueltas con la economía colaborativa. 2.1. Los fundamentos de la economía colaborativa. 2.2. Tipología de actuaciones colaborativas. 3. La alternativa del alojamiento colaborativo. 4. La naturaleza jurídica del alojamiento vacacional en viviendas particulares. 4.1. Normativa civil aplicable: arrendamientos de temporada y demás especies legales. 4.2. La aplicación de la normativa sectorial. 4.2.1. El estado de la cuestión fuera de nuestras fronteras. 4.2.2. El alquiler turístico de viviendas completas en España. 4.2.3. El alquiler turístico de habitaciones en viviendas en España. 5. La inexistencia de un marco normativo adecuado que otorgue garantías al usuario de este alojamiento colaborativo. 5.1. Protección de los usuarios turísticos. 5.2. Protección del medio ambiente y del territorio. 5.3. Protección de la economía. 6. El alojamiento colaborativo ¿es realmente colaborativo?

\section{INTRODUCCIÓN}

La llamada economía colaborativa, fenómeno innovador de alcance global y transversal, supone la apuesta por una alternativa a las prácticas hasta ahora conocidas en nuestra sociedad de consumo. Esta idea de la economía colaborativa ha tenido una gran repercusión más allá de su incidencia en los mercados de servicios y bienes, afectando de forma directa al sector del alojamiento turístico. De hecho, se han generalizado de forma extraordinaria diferentes alternativas al alojamiento vacacional más tradicional, mediante plataformas virtuales que ofrecen viviendas privadas para su uso turístico a precios competitivos y prometen experiencias más cercanas a la convivencia vecinal que turística. Estas opciones no están, sin embargo, exentas de polémica ya que en nuestro país no cuentan con una regulación jurídica propia, razón por la que el arrendamiento turístico de una habitación en una vivienda es considerada una actividad ilegal y clandestina. La disyuntiva que se

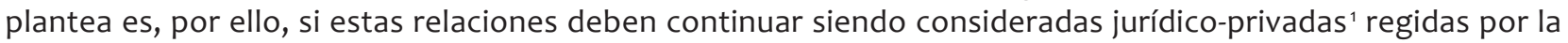
autonomía de la voluntad, o bien, si se les debe otorgar una ordenación jurídico-administrativa, convirtiendo así el contrato de hospedaje en una relación administrativa. Lo que está claro es que es necesaria la existencia de una regulación jurídica que otorgue garantías tanto al usuario en cuanto consumidor turístico, como a la propia comunidad en la que se desarrollan estas nuevas formas turísticas, equilibrando la convivencia vecinal en las zonas residenciales.

\section{A VUELTAS CON LA ECONOMÍA COLABORATIVA}

Resulta evidente que la sociedad está cambiando; la crisis financiera e inmobiliaria iniciada en 2007, junto a la posterior crisis de la deuda soberana y su respuesta por parte de la Unión Europea en forma de medidas de ajuste fiscal, han sumido a los países miembros en una era de austeridad ${ }^{2}$. Esta situación ha ampliado, sin duda, la base social de malestar y descontento con el sistema existente, que ha servido de acicate para la promoción de nuevas alternativas calificadas de post-materialistas, próximas a la cultura del decrecimiento. La reflexión sobre la que se sustenta esta apuesta por el decrecimiento se encuentra en la afirmación de que los valores imperantes en nuestra economía actual no son los que traen los mejores resultados, ni para las personas ni para las sociedades en su conjunto, por lo que deben modificarse y reemplazarse por otros 3 . Las dos ideas principales que están detrás de esta alternativa al orden establecido son, por un lado, que la relación entre crecimiento económico y bienestar no es lineal; y por otro, que los recursos de los que disponemos en el planeta son limitados.

Este modelo colaborativo intenta reinventar las estructuras tradicionales de mercado -a las que califica de efímeras y largamente caducadas- sustituyéndolas por otras más acordes con los valores que propugna, que aunque se resumen en el aumento del bienestar del ciudadano y abarcan consideraciones tales como las de justicia social, promoción de la confianza entre las personas o el intercambio de cultura y experiencia, resulta innegable la trascendencia positiva que también tienen sobre el medio ambiente, la eficiencia de recursos y la sostenibilidad ${ }^{4}$. Así, mediante aplicaciones y plataformas online, se crean puntos de encuentro de demanda y

1 RodríGUEZ-PIÑERo BRAVo-FERRER, M., “La intervención administrativa en la empresa hotelera”, en Primer Congreso Italo-Español de Profesores de Derecho Administrativo, Ministerio de Información y Turismo, Madrid, 1970, pp. $209-210$.

2 CONILL, J., CARDENAS, A., CASTELLS, M., SERVon, L., SVIATLANA, H., Otra vida es posible. Prácticas económicas alternativas durante la crisis, Barcelona, Editorial UOC, 2012, p. 232.

3 LATOUCHE, S., La apuesta por el decrecimiento ¿Cómo salir del imaginario dominante?, Barcelona, Icaria Antrazyt, 2006, p. 16. y KALLIS, G., “El futuro dialéctico del decrecimiento: ¿ficción distópica o proyecto emancipador?”, Revista de Economía Crítica, n. ${ }^{19}$, 2015 , pp. 21-33.

4 Esa colaboración no sólo se basa en la búsqueda de externalidades que puedan resultar de interés mutuo en términos competitivos, sino que sus integrantes defienden un principio ético de solidaridad que fundamenta una acción con objetivos transformadores, tal como plantean las propuestas sobre economía social y solidaria. Ese discurso supone defender una economía con valores en que la justicia social y

REALA, Nueva Época, - N. ${ }^{\circ}$, enero-junio 2016 - ISSN: 1989-8975 - DOI: 10.24965/reala.voi5.10350 
oferta de bienes y servicios infrautilizados que pueden ser compartidos, prestados, regalados, intercambiados, alquilados o comprados 5 . Si hasta ahora la propiedad era aquello a lo que debíamos aspirar, la disminución de la renta y el crédito disponible entre los consumidores a consecuencia de la crisis económica, junto al cambio cultural aparejado ${ }^{6}$, han supuesto la preferencia del uso sobre toda forma de propiedad; estos son los elementos para entender el auge de este modelo ${ }^{7}$. Nos movemos hacia nuevas formas de entender el consumo en las que lo que importa no es la propiedad sino más bien poder acceder al uso de tales bienes y servicios ${ }^{8}$; la posesión vence, pues, a la propiedad y lo inmaterial a lo material 9 .

Los precursores de esta filosofía alternativa de vida afirman que, sin lugar a dudas, si el siglo XX fue el del hiperconsumo basado en el crédito, la publicidad y la propiedad individual, el siglo XXI será el del consumo colaborativo a través de la reputación, la comunidad y el acceso compartido ${ }^{10}$. A juicio de algunos, estamos entrando en la Tercera Revolución Industrial", lo que supondrá el cambio de la era industrial a la era colaborativa.

\subsection{Los fundamentos de la economía colaborativa}

Un importante problema al que se enfrenta esta nueva tendencia es la de su propio significado. De hecho, es fácilmente perceptible que si bien en castellano hemos adoptado de forma general y casi unánime la expresión economía colaborativa, en inglés se emplean de forma sinónima diferentes fórmulas, como sharing-economy, peereconomy, collaborative economy o collaborative consumption y, a pesar de que sus significados sean bastante similares, no son exactamente iguales. Así, collaborative economy ${ }^{12}$ hace referencia a la forma de liberar el valor de los bienes en desuso o infrautilizados por su propietario, poniendo en común a quienes los necesitan pero no los tienen y a los que tienen pero no los usan, dejando de lado los canales tradicionales de intermediación y distribución ${ }^{13}$. Por su parte, collaborative consumption hace mención al sistema que reinventa los mercados tradicionales de venta, alquiler, intercambio, trueque, participación, etc., en nuevas formas impensables antes de la existencia de Internet ${ }^{14}$. Mientras que sharing-economy significa compartir -no ceder- bienes o servicios en desuso o infrautilizados, generalmente de forma gratuita y directa entre particulares o entre empresas ${ }^{15}$. En cualquier caso y a pesar de la confusión terminológica, el núcleo común alberga un sentido de colaboración en cuanto al uso de capacidades sin utilizar y a un proceso de cambio de valores sociales y humanos (comunidad, confianza, compartir) en el que existe un intercambio recíproco entre dos partes, bien sin ninguna retribución a cambio, bien a través del intercambio de bienes y servicios por dinero, puntos o tiempo ${ }^{16}$. Todas ellas aluden, en definitiva, a los nuevos sistemas de producción y consumo de bienes y servicios que surgen a principios del siglo XXI y que aprovechan las posibilidades abiertas por los recientes avances de las tecnologías informáticas para intercambiar y compartir dichos bienes y servicios ${ }^{17}$. Se trata, en definitiva, de formas de compartir que tienen en común la inexistencia de ánimo de lucro.

espacial o la sostenibilidad primen sobre la maximización del beneficio y la acumulación, la cooperación sobre la competencia entre desiguales, el trabajo sobre el capital, o la responsabilidad compartida sobre la centralización del poder de decisión, aspectos clave para avanzar hacia un desarrollo local más integrador. Véase MÉNDEZ, R., "Redes de colaboración y economía alternativa para la resiliencia urbana: una agenda de investigación”, Revista Bibliográfica de Geografía y Ciencias Sociales, n. 1139, 2015, p. 6.

5 Dictamen del Comité Económico y Social Europeo sobre «Consumo colaborativo o participativo: un modelo de sostenibilidad para el siglo XXI», 21 y 22 de enero, 2014. Puede consultarse online en http://eur-lex.europa.eu/legal-content/ES/TXT/?uri=CELEX:52013IE2788.

6 Para Zelizer, toda crisis económica lleva aparejada una crisis cultural que hace que ciertos valores ya no sean sostenibles (ZELIZER, V., Economic Lives: How Culture Shapes the Economy, Princeton University Press, 2010, p. 3).

7 “Consulta pública sobre los nuevos modelos de prestación de servicios y la economía colaborativa” realizada por la Comisión Nacional de los Mercados y la Competencia, en adelante CNMC. Disponible online en https://sites.google.com/site/rprelim/

8 GANSKY, L., La malla, el futuro de los negocios es compartir, Barcelona, Ediciones Gestión 2000, 2011.

9 Lo que se afirma es que access is better than ownership. Véase KELLY, K., “Better than owning”, The Technium, 2009; disponible online en http://kk.org/thetechnium/better-than-own/

10 BOTSMAN, R., ROGERS, R., What's mine is yours: the rise of collaborative consumption, Nueva York, Harpers Collins Publishers, 2010.

11 RifKING, J., La civilización empática. La carrera hacia una conciencia global en un mundo en crisis, Barcelona, Paidós, 2010, p. 14. BoIX, en cambio, al referirse a las transformaciones que estos cambios están provocando en la forma con la que el Derecho se enfrenta a ellos, los denomina "tercera revolución productiva" (BoIx PALOP, A., "De McDonald's a Google: la ley ante la tercera revolución productiva”, Teoría y Derecho: Revista de Pensamiento Jurídico, n. ${ }^{\circ} 1,2007$, p. 124).

12 Véase Sharing-Economy, Dictionary of commonly used terms, en el blog Collaborativeconssumption.com. Recurso disponible online en: http://www.collaborativeconsumption.com/2015/11/12/the-sharing-economy-dictionary-of-commonly-used-terms/.

13 Es el caso de Vandebron, que permite la obtención de energía directamente de quienes la producen de forma independiente.

14 Son buen ejemplo de ello no solo AirBnb y eBay, sino también otras plataformas que permiten, por ejemplo, pedir dinero prestado a particulares, como Zopa, Prosper o LendingClub.

15 Como los bancos de tiempo, en la que se comparte el tiempo de cada uno, empleándolo de diferentes modos. También la App Cohealo, que permite a los hospitales compartir equipamiento cuando no está en uso. Otras Apps para compartir son ParkAtMyHouse o Comparko, que permiten a los usuarios compartir el uso de una plaza de parking durante las horas en que su propietario no la utiliza.

16 BOtSMAN, R., ROGERS, R., What's mine is yours. The rise of collaborative consumption, op. cit. p. 17.

17 DOMÉNECH PASCUAL, G., “La regulación de la economía colaborativa (Uber contra el taxi), Revista CEF Legal, revista práctica de Derecho, n. ${ }^{\circ} 175-176,2015$, pp. 61-104, p. 65. 
Ciertamente, la innovación tecnológica y el mejor acceso a la información han facilitado que el fenómeno de la economía colaborativa se haya popularizado a una velocidad vertiginosa gracias a la construcción de redes de colaboración a nivel internacional, como forma de organización, entre individuos, empresas o entidades sociales. Entre sus miembros se comparten bienes y/o servicios, pero también información y conocimiento, lo que sin duda aumenta la eficiencia colectiva, la creatividad social y una democracia más participativa ${ }^{18}$, reduciendo los costes de transacción y de intermediarios. De ahí que se encuadre esta economía colaborativa en las innovaciones socio-digitales construidas en base a la tecnología, dado que son las plataformas online las que permiten a los usuarios formar parte de estructuras económicas bajo demanda (peer-to-peer o su acrónimo p2p) a una escala inimaginable hasta el momento ${ }^{19}$. Estas plataformas virtuales, que han proliferado acompañando al frenético desarrollo del fenómeno colaborativo, han encontrado diferentes nichos de mercado en múltiples sectores de la economía y de la sociedad, aunque destacan especialmente en el sector del denominado alojamiento colaborativo y en el del taxi y uso compartido de vehículos. De ahí que se haya propuesto, como alternativa a la denominada peer-to-peer economy o economía de igual a igual, acuñar la expresión «prestación de servicios a través de plataformas virtuales», por ser mucho más descriptiva y neutra a la hora de describir este nuevo modelo de negocio ${ }^{20}$.

Sin embargo, este fenómeno colaborativo, aunque calificado de puntero y novedoso, es algo que ha existido siempre. Compartir, intercambiar, prestar, incluso regalar bienes, productos o servicios ha sido y es propio de muchas sociedades. Nuestros ancestros aunaban esfuerzos para que las tareas de caza, agrícolas o de construcción resultaran más sencillas, y el altruismo nacía de manera espontánea cuando esa interacción se repetía en el tiempo. Ahora bien, compartir no es una característica innata en el hombre sino que está fuertemente influenciado por la cultura. La teoría de la economía colaborativa sugiere que los ciudadanos asumen de forma colectiva el coste de un bien concreto que no pueden asumir de forma individual ${ }^{21}$; de manera que, a la inversa, la riqueza reduce lo colaborativo. Para Belk, este fenómeno es la acción y el proceso de distribuir lo que es nuestro entre los demás para que lo usen y/o el acto y proceso de recibir o coger de otros para nuestro uso propio ${ }^{22}$ e incluye entre estas acciones las que se realizan de forma voluntaria y legal. Ahora bien, las acciones que se llevan a cabo al margen de la normativa o en contra de la voluntad de las propietarias y propietarios de los bienes también son considerados por diversos autores como parte de la economía colaborativa, que fundamentan comportamientos como la ocupación ilegal de inmuebles basadas en razones de igualdad y justicia por ser igualmente necesarias para la consecución de resultados de sostenibilidad medioambiental ${ }^{23}$.

Por ello, no creemos que se pueda sostener que este fenómeno sea, en realidad, algo novedoso en lo que respecta a su contenido, aunque sí en cuanto a su forma dado que ha sido el uso de las nuevas tecnologías de la comunicación y de la información lo que ha servido de catalizador para que las fórmulas del compartir, ya caídas en desuso, vuelvan a estar de plena actualidad. Como decimos, sin embargo, no se trata de nada nuevo. La única diferencia existente entre la novedosa economía colaborativa y los trueques e intercambios que se han hecho toda la vida en nuestras sociedades es la forma de acceder a ellos, puesto que en la actualidad se hace a través de las nuevas tecnologías, lo que permite un consumo mucho más eficiente y un mayor conocimiento de la oferta disponible. Vivimos en un mundo global donde podemos imitar los intercambios que antes tenían lugar cara a cara, pero a una escala y de una manera que hasta ahora no había sido posible ${ }^{24}$. La utilización de las TIC permite reducir de manera muy considerable los costes de transacción y las asimetrías informativas ${ }^{25}$, abaratando exponencialmente las actividades de obtención, almacenamiento, procesamiento y comunicación de la información necesarias para identificar, localizar, conocer y poner en contacto a multitud de personas interesadas en celebrar acuerdos mutuamente beneficiosos. La eficiencia de Internet, combinada con la capacidad de generar confianza entre extraños ha creado un mercado eficiente de intercambios entre productor y consumidor, prestador y prestatario, y entre vecino y vecino, sin intermediarios.

18 MÉNDEZ, R., “Redes de colaboración y economía alternativa para la resiliencia urbana: una agenda de investigación”, op. cit., p. 5

19 BOTSMAN, R., ROGERS, R., What's mine is yours. The rise of collaborative consumption, op. cit. p. 19.

20 Como sostiene Todolí, la economía bajo demanda (o como propone, la «economía basada en la prestación de servicios a través de plataformas virtuales») es un término-paraguas que recoge un conjunto de negocios bastante diferentes entre sí, aunque todos compartan la idea de la utilización de una plataforma virtual donde oferta y demanda se encuentran. Véase TODOLí SIGNES, A., "El Impacto de la "Uber economy" en las relaciones laborales: los efectos de las plataformas virtuales en el contrato de trabajo", luslabor, n. ${ }^{\circ}$ 3, 2015 , p. 7.

21 VÖLKER, B., FLAP, H., "Sixteen million neighbors: a multilevel study of the role of neighbors in the personal networks of the Dutch" Urban Affairs Review, vol. 43, n. ${ }^{\circ}$ 2, 2007, p. 261.

22 BELK, R., "Sharing”, Journal of Consumer Research, vol. 36, n. ${ }^{\circ}$ 5, 2010, p. 717.

23 AGYemAN, J., McLaren, D., SCHAEFER-BorReGo, A., "Sharing cities", Friends of the Earth, disponible online en: http://gmlip.ontheplatform.org.uk/sites/default/files/agyeman_sharing_cities.pdf.

24 BOtSMAN, R., ROGERS, R., What's mine is yours. The rise of collaborative consumption, op. cit. p. xv.

25 Las asimetrías informativas hacen referencia a situaciones en las que una de las potenciales partes posee más o mejor información que la otra sobre circunstancias de las que dependen los resultados del negocio (DomÉnECH PASCUAL, G., "La regulación de la economía colaborativa (Uber contra el taxi), op. cit., pp. 68-69).

REALA, Nueva Época, - N. ${ }^{\circ}$ 5, enero-junio 2016 - ISSN: 1989-8975 - DOI: 10.24965/reala.voi5.10350 
Por esta razón, aunque se habla de reinventar los modelos que conocemos, más bien deberíamos hablar de re-escribir o re-etiquetar instituciones que ya eran conocidas e implementadas por nuestros mayores ${ }^{26}$. Como ya hemos dicho, no hay nada nuevo bajo el sol; otra cosa es cómo se está desarrollando, adaptándolo a las nuevas formas de acceso tecnológico y a las nuevas necesidades de la población.

\subsection{Tipología de actuaciones colaborativas}

Es cierto que este fenómeno ha ganado visibilidad y presencia de unos años a esta parte; de hecho, no es casualidad que las plataformas virtuales comiencen su andadura a partir de 2008, coincidiendo con las alertas de crisis económica a nivel mundial. Pero es en 2012 cuando comienza el reinado de la economía colaborativa, bajo las formas ideadas por Botsman en su libro, al que se ha bautizado como la «biblia» de la economía colaborativa²7. Esta autora sostiene que esta nueva actividad colaborativa puede resumirse en tres tipos distintos de actuación: los sistemas de servicio de productos, los sistemas de redistribución y el denominado estilo de vida colaborativo.

El primer tipo es el denominado sistema de servicio de productos -PSS o Product Service System-. Se trata de un nuevo modelo de servicio por el que se le proporcionan a los consumidores los servicios que requieren de forma concreta, de manera que estos pueden disfrutar de un bien o servicio puntualmente sin necesidad de que adquieran su propiedad. El beneficiario paga por utilizar dicho servicio y en dicho pago se incluye no sólo el bien en sí, sino también su mantenimiento, de forma que se convierte en una manera totalmente sostenible de proporcionar servicios, con un bajo impacto ambiental derivado de la reducción de las unidades que se deben producir. Un ejemplo es el que se lleva a cabo en Alemania por la empresa Volkswagen, que se ha asociado con diversos complejos inmobiliarios para ofrecer servicios de movilidad a los arrendatarios residentes a través de dos programas, Mietermobil y Wonh Mobil, por los que se suministraban vehículos de diferentes gamas de la marca, con mantenimiento y limpieza a cargo de Volkswagen ${ }^{28}$.

El segundo se refiere a los sistemas de redistribución -redistribution market-como aquellos encargados de redireccionar los bienes de segunda mano o sin uso a quienes los necesiten. Un mercado de intercambio es una agrupación de personas de un mismo territorio que tienen por objetivo intercambiar bienes y servicios entre ellos, sin usar dinero, a través del trueque ${ }^{29}$ o se venden a precios competitivos. Son los mercados de segunda mano o de intercambio ampliamente conocidos -flea markets; marché aux puces; mercato delle pulci-. Los tradicionales anuncios clasificados de segunda mano han dado paso a las aplicaciones informáticas y a las redes de intercambio que realizan estas actividades con un soporte virtual.

El último de los sistemas ideados por esta autora hace referencia al estilo de vida colaborativo que deriva de la propia ideología que defiende. Aúna todas aquellas iniciativas que no se centran en compartir bienes materiales y servicios, sino que van más allá, a los bienes inmateriales, no tangibles. No sólo se comparten espacios sino también conocimientos, habilidades, formas de pensar, incluso tiempo. Se propugna, así, una nueva filosofía de vida comunal en la que los beneficios no son solo económicos sino emocionales ${ }^{30}$, como los sentimientos de ayuda mutua y o de inteligencia por consumir de una manera más racional y eficiente, al tiempo que se ensalzan los valores de solidaridad, comunidad y colaboración entre las personas.

\section{LA ALTERNATIVA DEL ALOJAMIENTO COLABORATIVO}

La pregunta obligada es la siguiente ¿el modelo colaborativo resulta aplicable al mercado inmobiliario turístico? Sin duda. Como venimos observando, asistimos a una nueva transformación del imaginario social que se debe, en gran parte, al soporte tecnológico ya que se utilizan las herramientas tecnológicas como catalizadores de la participación ciudadana, desarrollando una nueva conciencia del espacio compartido y permitiendo la emergencia de las sinergias

26 Ya en 1970, se acuñó el concepto de «prosumo» y más adelante, el de «prosumidores», para hacer referencia a quienes consumen lo que producen, lo que ponía de manifiesto que la revolución industrial había separado las funciones de producción y consumo, lo que hizo que la gente pasara de «producir para el uso» a «producir para el intercambio» (CONILL, J., CARDENAS, A., CASTELLS, M., SERVON, L., SVIATLANA, H., Otra vida es posible. Prácticas económicas alternativas durante la crisis, op. cit., p. 29).

27 BOTSMAN, R., ROGERS, R., What's mine is yours. the rise of collaborative consumption, op. cit., p. XVI.

28 Las ventajas que reporta este sistema son diversas, como la reducción de gastos generales de los consumidores ya que se elimina la necesidad de comprar un coche por persona o familia; la disminución del impacto ambiental no sólo porque los vehículos son mantenidos en perfecto estado por un concesionario local, sino también porque se reduce el espacio de parking necesario al haber menos coches en uso; se trata, asimismo, de una forma de hacer más atractiva la oferta de alquileres al suponer una mejora sobre las condiciones del mismo; y, por supuesto, es una forma eficiente de promover la movilidad ya que se proporcionan diferentes tamaños de vehículos para adaptarse a las necesidades del usuario. Véase el Informe Anual de Volkswagen, 2000.

29 Conill, J., CARdenAs, A., CAStells, M., Servon, L., SviatlanA, H., Otra vida es posible. Prácticas económicas alternativas durante la crisis, op. cit., p. 67.

30 CAÑIGUERAl BAGó, A, Vivir mejor con menos. Descubre las ventajas de la nueva economía colaborativa, Barcelona, Conecta, 2014, p. 51.

REALA, Nueva Época, - N. ${ }^{\circ}$ 5, enero-junio 2016 - ISSN: 1989-8975 - DOI: 10.24965/reala.voi5.10350 
entre individuos activos y comprometidos. Fruto de esta nueva conciencia social nace el controvertido alojamiento colaborativo, rodeado de polémica no sólo en cuanto a su denominación sino, sobre todo, en cuanto a su regulación y a las distintas modalidades de su puesta en práctica, tanto en nuestro país como fuera de nuestras fronteras.

A día de hoy, el grueso de las iniciativas colaborativas se da en este sector del alojamiento turístico ${ }^{31}$. Si la idea base de la economía colaborativa es la de reaprovechar los recursos de los que disponemos, permitiendo su uso a terceras personas ¿por qué no hacer lo mismo con la vivienda? Algo que hasta ahora conocíamos como intercambio de casas, muy de moda hace varios años y que consistía en la permuta temporal y gratuita de la propia vivienda durante los períodos vacacionales, se ha convertido en un lucrativo negocio para algunos gracias a la proliferación de las plataformas online de alquiler de pisos y habitaciones ${ }^{32}$. Estas nuevas empresas, que cuentan con multitud de usuarios en Europa y Estados Unidos, suponen un actor añadido en el tradicional mercado hotelero ${ }^{33}$. Mediante esta nueva modalidad alojativa, las propietarias y propietarios de viviendas o de cualquier habitáculo susceptible de ser utilizado como alojamiento, las publicitan a través de medios online, poniéndolas a disposición temporal de potenciales clientes a cambio de un precio.

Es evidente que lo colaborativo también ha llegado al sector inmobiliario y las nuevas posibilidades de intermediación tecnológica favorecen esta tendencia al reducir los costes de transacción pero, sobre todo, al ampliar de forma prácticamente ilimitada las redes de intercambio. Las plataformas colaborativas, que se han convertido en los nuevos actores del mercado del alojamiento turístico, son según la CNMC, mercados de varios lados, en las cuales cada uno de los lados del mercado recibe valor por la existencia del otro o de los otros dos lados, al tiempo que se benefician mutuamente de un efecto red y realizan la función de catalizador entre los distintos lados del mercado, permitiendo resolver el problema de coordinación entre la oferta y la demanda ${ }^{34}$.

La polémica surge, sin embargo, por tres motivos. El primero tiene que ver con la propia naturaleza de estas nuevas formas de alojamiento vacacional, ya que a día de hoy las ofertas existentes en estas plataformas posibilitan los alquileres no sólo de viviendas completas sino, sobre todo, la de habitaciones dentro de la misma vivienda, en todos los rangos de pernoctas posibles; algunas de estas situaciones, como veremos, no tienen cabida en nuestro ordenamiento jurídico por el momento. El segundo de los motivos es la inexistencia de garantías que protejan al usuario del alojamiento turístico y al entorno de la vivienda, lo que puede derivar no sólo una merma de la calidad de la oferta turística de nuestro país, sino también en que los propios ofertantes del alojamiento puedan incurrir en diversas infracciones administrativas. Por último, otro de los grandes problemas a los que se enfrenta esta nueva forma de alojamiento está directamente relacionado con la esencia de la economía colaborativa, ya que se cuestiona si este tipo de servicio puede ser calificado de colaborativo o si más bien estamos ante un nuevo modelo de negocio. Veamos estos tres puntos con algo más de detalle.

\section{LA NATURALEZA JURÍDICA DEL ALOJAMIENTO VACACIONAL EN VIVIENDAS PARTICULARES}

El primero de los problemas a los que se enfrenta esta nueva modalidad de alojamiento vacacional es su encuadre jurídico. Como toda transformación económica disruptiva, la economía colaborativa supone un cambio de

31 De acuerdo a la Decisión de la Comisión 99/34/CE, de 9 de diciembre de 1998, sobre los procedimientos de aplicación de la Directiva 95/57/CE del Consejo sobre la recogida de información estadística en el ámbito del turismo (DOCE n. ${ }^{\circ}$ 9, de 15-1-99), un alojamiento turístico es cualquier estructura empresarial que presta un servicio de alojamiento regularmente. El alojamiento colectivo es aquel que constituye una actividad empresarial regular, que consiste en ofrecer al turista la posibilidad de pernoctar en una habitación u otro espacio acondicionado para el alojamiento, siendo su capacidad mayor a un determinado número de camas. Mientras que define el alojamiento privado por la particularidad añadida de que se trata de alojamientos que no son empresas convencionales y que disponen de una capacidad limitada.

32 Las plataformas que ofrecen a día de hoy ofertas de turismo vacacional p2p crecen exponencialmente; a día de hoy encontramos AirBnb Inc.; BedyCasa; Wimdu; 9Flats; HomeAway; Niumba; Rentalia; Only-Apartments; BizPora; SinpaSpain; WWOOF; Workaway; BeMate; KarmatHome; WorkyLand; FlatClub; WarmShowers; huntbnb; BeyondPricing; BarcelonaCheckIn; Knock; MyTwinPlace; MisterBnB; OneFineStay; IntercambiodeCasa; Intervac; HomeCompartia; HappyHamlet; NightSwapping; GoCambio; BeHomm; BedRural; CasaVersa, entre otras muchas.

Fuera del terreno vacacional, existen otras muchas alternativas diferentes dentro de la denominada vivienda colaborativa, como el housesitting que ofrece alojamiento a cambio de cuidar una casa. Pero también el colaboracionismo ha llegado a los espacios de trabajo, como la plataforma Co-workingSpain, que alquila espacios para trabajar; LiquidSpace, OpenDesks, PivotDesks o DeskSurfing, que sirven para localizar y alquilar espacios de trabajo en todo el mundo por días, meses, o incluso por horas.

33 Sobre este particular, véase JIMÉNEZ SOTO, I., “Ordenación de los servicios turísticos: competencias administrativas y unidad de mercado”, ponencia presentada en el XXI Congreso Italo-Español de Profesores de Derecho Administrativo, celebrado en Alicante los días 26,27 y 28 de mayo de 2016 (disponible online en http://deje.ua.es/es/derecho-administrativo/documentos/ponencias-congreso-profesores-administrativo/ponencia-ignacio-jimenez-soto.pdf). También MARZAL RAGA, R., “Unidad de mercado y clasificación hotelera”, comunicación presentada en el mismo Congreso (disponible online en http://deje.ua.es/es/derecho-administrativo/cursos/xxi-congreso-italo-espanol-de-profesores-dederecho-administrativo-ponencias-y-comunicaciones.html).

34 Conclusiones preliminares sobre los nuevos modelos de prestación de servicios y la economía colaborativa, de la Comisión Nacional de los Mercados y la Competencia, marzo, 2016; disponible online en https://docs.google.com/document/d/1n65MjUaTmRLuZCqTIlqyWvobVq reR-iAzsz1mhxy2yo/edit?pref=2\&pli=1.

REALA, Nueva Época, - N. ${ }^{\circ}$ 5, enero-junio 2016 - ISSN: 1989-8975 - DOI: 10.24965/reala.voi5.10350 
paradigma y, en cuanto se refiere al alojamiento, constituye una nueva perspectiva frente a las formas habituales de hospedaje en cualquiera de sus segmentos. El amplio abanico de posibilidades previsto por estas plataformas virtuales choca de lleno con la normativa tradicional que, como veremos, sólo ha establecido regulación ad hoc en el caso de la cesión de uso turística de la vivienda, no permitiendo la cesión por estancias o habitaciones.

Por lo que se refiere al encuadre jurídico de este alojamiento colaborativo, las cesiones de uso de las viviendas de forma temporal y mediante contraprestación se han articulado tradicionalmente, como sabemos, a través de la figura del arrendamiento previsto en el Código Civil. No obstante, dada su finalidad, es evidente que este arrendamiento civil podría dar paso a otro tipo de contratos más propios de la actividad turística, dado que en la misma se engloban ciertos servicios a los que no están obligados quienes suscriben un contrato de arrendamiento 35 , tal y como recogía la ya derogada Orden de 17 de enero de 1967, que aprobaba la ordenación de los apartamentos, bungalows y otros alojamientos similares de carácter turístico. Veamos estas dos posibilidades.

\subsection{Normativa civil aplicable: arrendamientos de temporada y demás especies legales}

Veamos, en primer lugar, si esta figura tendría encaje dentro de los arrendamientos civiles. La Ley de Arrendamientos Urbanos (Ley 29/1994, de 24 de noviembre, en adelante LAU) establece que un arrendamiento de vivienda es aquél que recae sobre una edificación habitable para satisfacer la necesidad permanente de vivienda del arrendatario (art. 2.1. ${ }^{\circ}$ ), por un plazo mínimo de tres años salvo pacto en contrario (art. 36).

Lógicamente, estas cesiones turísticas de la vivienda no pueden ser enmarcadas en este tipo de contrato dado que carecen de la característica vocación de permanencia. Por ello, otra posibilidad sería su consideración como arrendamiento de temporada, ya que según establece la propia LAU, éstos lo serán cuando recayendo sobre una edificación no tengan como destino primordial la satisfacción permanente de vivienda del arrendatario (arts. 3.2. $.^{\circ}, 29$ y ss. LAU); se trata de arrendamientos de uso distinto al de vivienda, ya sea de verano, ya sea para ejercer actividades industriales, comerciales, etc. ${ }^{36}$. En este caso, sería posible la consideración de estas cesiones de uso siempre que se tratase de viviendas completas, esto es, edificaciones habitables, puesto que la Ley de Arrendamientos no prevé el alquiler de temporada por habitaciones dentro de una vivienda. De forma que el régimen jurídico aplicable a estos alquileres turísticos de habitaciones sería únicamente posible entendiéndolo como un arrendamiento de cosa, según lo establecido en los artículos 1542 y 1543 del Código Civil ${ }^{37}$, lo que resultaría ciertamente extraño a la vista de que parece reunir todos los requisitos para considerarla, por un lado, un alojamiento y, por el otro, una explotación turística.

35 El alquiler de vivienda es una transferencia de uso temporal y onerosa de la misma, cuyo arrendador no se obliga a prestar servicio ni actividad alguna en beneficio del arrendatario, a diferencia de la característica del alojamiento turístico, donde se ofrece la asistencia que recibe el cliente desde el momento de la ocupación de la vivienda, sin desvirtuar su naturaleza el hecho de que se presten todos o solamente algunos de los servicios (FrANCH FLUXÁ, J. y RIBAS CONRADO, J.F., “El alquiler de viviendas para uso vacacional. Perspectiva actual, problemas y propuestas legales", Estudios Turísticos, n. ${ }^{\circ}$ 195, 2013, p. 40). Es esta prestación de determinados servicios la que se erige en pieza clave para calificar una actividad locativa como actividad turística (CAMPUZANO TOMÉ, H., "El alquiler de viviendas de uso turístico a partir de la Ley 4/2013: la necesaria interpretación conjunta de la LAU y de la legislación turística autonómica”, Revista Crítica de Derecho Inmobiliario, n. ${ }^{\circ} 749,2015$, p. $^{2}$ 1205), de ahí que sea considerado, en definitiva, un arrendamiento complejo constituido por una agrupación de otros más simples y de distinta naturaleza, como el de cosa por la cesión del apartamento propiamente dicho; el de arrendamiento de servicios, por los de índole personal que está obligado el arrendador o su mediador y el precio ha de comprender forzosamente servicios básicos, así como los gastos generales inherentes a la vivienda (FRANCH FLUXÁ, J. y RIBAS CONRADO, J.F., "El alquiler de viviendas para uso vacacional. Perspectiva actual, problemas y propuestas legales”, op. cit., p. 43. En el mismo sentido, VERDERA IzQUIERDO, B., "La problemática del turismo residencial”, Diario La Ley, n. 7297, 2009, p. 9).

36 Nuestro Tribunal Supremo ha venido señalando que la nota esencial que caracteriza a los arrendamientos de temporada es que no satisfacen la necesidad permanente que el arrendatario tiene de ocuparla para que le sirva de residencia habitual de la familia, sino para desarrollar de una manera accidental, en épocas determinadas, actividades distintas de aquellas que vienen pautadas por los cotidianos hábitos de vida, responsabilidades y exigencias laborales, siendo indiferente la mayor o menor frecuencia de su utilización, así como la duración del arriendo, ya que el requisito de temporalidad de la ocupación guarda relación, no con el plazo de vigencia cronológico, sino con la finalidad a la que va encaminado el arrendamiento determinante de su ocupación. Sólo la permanente y perentoria necesidad de ocupación del inmueble por parte del inquilino justifica la aplicación de los derechos y medidas de reforzada protección que la LAU otorga al arrendatario (STS de 4 de abril de 2011, Rec. 1932/2007, Pte. Xiol Ríos).

Para Román Márquez, esta figura ha sido la utilizada en fraude de ley durante años para suplantar la normativa específicamente turística por aquellos propietarios que alojaban a sus huéspedes temporales, con una finalidad inequívocamente turística, sin haber sido objeto de ningún reproche de carácter jurídico más allá de las cuestiones exclusivamente fiscales (RomÁN MÁRQUEZ, A., "Las viviendas particulares dedicadas a la actividad de alojamiento turístico. Su exclusión de la Ley de arrendamientos urbanos", Revista Internacional de Doctrina y Jurisprudencia, n. ${ }^{\circ} 1,2014$, p. 4. Más sobre esta cuestión en VERDERA IZQUIERDO, B., "El arrendamiento de temporada frente a las estancias turísticas en viviendas", El consultor Inmobiliario, n. ${ }^{0} 107,2009$, pp. 1-17).

37 El artículo 1542 CC establece que el arrendamiento puede ser de cosas, o de obras o servicios. Mientras que el artículo 1543 CC sostiene que en el arrendamiento de cosas, una de las partes se obliga a dar a la otra el goce o uso de una cosa por tiempo determinado y precio cierto.

REALA, Nueva Época, - N. ${ }^{\circ}$ 5, enero-junio 2016 - ISSN: 1989-8975 - DOI: 10.24965/reala.voi5.10350 
Consciente de esta situación, el legislador ha sometido a la LAU a una sustancial modificación operada por la Ley $4 / 2013$, de 4 de junio, de medidas de flexibilización y fomento del mercado del alquiler de viviendas ${ }^{38}$. La razón de dicha reforma, tal y como se recoge en la Exposición de Motivos de esta ley, es el significativo aumento del uso del alojamiento privado para el turismo en los últimos años que podría estar dando cobertura a situaciones de intrusismo y competencia desleal ${ }^{39}$, que van en contra de los destinos turísticos. Esta es la razón por la que la reforma excluya de forma concreta estos supuestos ${ }^{40}$ para que queden regulados por la normativa sectorial específica o, en su defecto, se les aplique el régimen de los arrendamientos de temporada, que no sufre modificación. La modificación realizada sobre la LAU, en cuanto a los arrendamientos excluidos se refiere, establece de forma expresa que no constituye arrendamiento sometido a dicha ley la cesión temporal de uso de la totalidad de una vivienda amueblada y equipada en condiciones de uso inmediato, comercializada o promocionada a través de canales de oferta turística ${ }^{41}$ y realizada con finalidad lucrativa, cuando esté sometida a un régimen específico, derivado de su normativa sectorial (art. 5.e LAU).

De este modo, habrá que estar principalmente a la normativa sectorial que sobre esta cuestión se establezca en aplicación del principio de ley especial; y sólo en defecto de esta normativa sectorial específica o cuando no se reúnan los requisitos que en aquélla se establezca, se les aplicará el régimen de los arrendamientos de temporada ${ }^{42}$. Por el momento todo apunta a que la única regulación se está realizando a nivel autonómico.

\subsection{La aplicación de la normativa sectorial}

La segunda posibilidad es que este tipo de alojamiento se resuelva como una modalidad de estancia turística en vivienda dado que parece reunir los requisitos que, de forma general, se exigen para determinar la existencia de una explotación turística, como es el desarrollo de actividades propias de la prestación de un servicio de alojamiento turístico entre las que se incluyen las de gestión, administración y dirección comercial, además del hecho de que se publiciten a través de los canales de oferta turística ${ }^{43}$.

38 Sobre esta reforma, véase NASARRE AZNAR, S., "La eficacia de la Ley 4/2013, de reforma de los arrendamientos urbanos, para aumentar la vivienda en alquiler en un contexto europeo", Revista Crítica de Derecho Inmobiliario, n. ${ }^{\circ} 747,2015$, pp. 205-249. También DE LA IGLESIA PrADOS, E., "La reforma en la regulación del contrato de arrendamiento urbano de vivienda de junio de 2013 ”, Actualidad Civil, n. ${ }^{\circ} 11,2013$, pp. 1-12, p. 3 y 4 . Asimismo CARrasco PererA, Á., "Comentarios al proyecto de ley de reforma de los arrendamientos de viviendas, Revista de Derecho de Consumo, n. ${ }^{\circ}$ 4, 2012, pp. 118-134. Y NúÑEZ IGLESIAS, Á., “Tipología de los contratos de alojamiento extrahotelero (I)”, Actualidad Civil n. ${ }^{\circ} 12,2010$, pp. 1-20.

39 Como sabemos, ya existe un pronunciamiento judicial que recoge que efectivamente una actividad propia de la economía colaborativa supone competencia desleal para un sector económico. En el Auto de 9 de diciembre de 2014, el Juzgado de lo Mercantil n. 2 de Madrid (proc. 707/2014) autoriza la adopción de la medida de suspensión cautelar de las actividades de esta empresa por cuanto el hecho de realizar servicios de transporte sin la preceptiva autorización administrativa puede suponer una actividad concurrencial ilícita que implica actuación desleal.

40 Recordemos que, bajo el Decreto 231/1965, de 14 de enero, por el que se aprueba el estatuto ordenador de las empresas y actividades turísticas privadas (art. 2.2) y del real Decreto 1634/1983, de 15 de junio, sobre ordenación de establecimientos hoteleros (art. 1.a), no había contrato de alojamiento o de hospedaje sino subarriendo de la vivienda, sometido a la Ley de Arrendamientos Urbanos, cuando un particular que no desarrollase una actividad empresarial, cedía a un huésped el uso de una habitación de su vivienda a cambio de un precio. Véase BLANQUER CRIADO, Derecho del Turismo, Valencia, Tirant lo Blanch, 1999, pp. 387-388.

41 De las opiniones mantenidas por la doctrina se desprende que el concepto de canal turístico es equivalente al de agente intermediador que actúa a través de las redes digitales, esto es, agencias de viajes, agencias inmobiliarias e Internet. Para algunos autores, Internet no resulta sinónimo de canal turístico por dejar excluidos del alcance del artículo 5.e) LAU a los arrendamientos en los que el particular, sin acudir a un canal de oferta turístico, arrienda su apartamento por Internet (GONZÁLEZ CARRASCO, C., "El nuevo régimen de los arrendamientos de vivienda tras la ley de medidas de flexibilización y fomento del mercado del alquiler”, Revista de Derecho de Consumo, n. ${ }^{\circ} 6$, 2013, pp. 170190, p. 180), mientras que para otros no es lo que determina que quede excluido del ámbito de aplicación de la LAU (CAMPUZANO TOMÉ, H., "El alquiler de viviendas de uso turístico a partir de la Ley 4/2013: la necesaria interpretación conjunta de la LAU y de la legislación turística autonómica", op. cit., pp. 1230-1231), para quien la mera participación de un intermediario en el alquiler de la vivienda para uso turístico con la finalidad de poner a las partes en contacto y facilitar la celebración del contrato no es suficiente para conceder a un arrendamiento de temporada para uso vacacional la categoría de alquiler turístico, salvo que se trata de empresas de intermediación turística o que, además de la actividad de alojamiento, conlleven la prestación de otro tipo de servicios.

42 Sin embargo, para Martínez Cañellas, esta interpretación no es factible por inconstitucional. En su opinión, las Comunidades Autónomas no disponen de competencias en materia de regulación civil de los contratos de alojamiento o de arrendamiento, a excepción de Cataluña. En su opinión, es inconstitucional aquella normativa sectorial autonómica que prohíba o limite la cesión temporal de uso de la totalidad de una vivienda amueblada y equipada en condiciones de uso inmediato, comercializada o promocionada en canales de oferta turística y realizada con finalidad lucrativa; sin embargo, esta posible inconstitucionalidad no impide que la Comunidad Autónoma pueda regular las condiciones en las que este tipo de cesiones se consideren oferta ilegal e imponer sanciones administrativas a este tipo de contratos. Véase MARTíNEZ CAÑELLAS, A., "La cesión del uso de la vivienda a no residentes: contrato de alojamiento (de estancias turísticas) en viviendas y el contrato de arrendamiento de temporada, conforme a la Ley del Turismo de las Islas Baleares tras la reforma de la Ley de Arrendamientos Urbanos" Boletín de la Academia de Jurisprudencia y Legislación de las Illes Balears, n. ${ }^{15}$, 2014, pp. 157-158.

43 Entre otras, véase la STS de 17 de septiembre de 1993 (Rec. 2502/1991, Pte. Yagüe Gil), que dice que lo que diferencia un apartamento turístico de las viviendas turísticas vacacionales es que las primeras deben estar dotadas de mobiliario, instalaciones, servicios y equipo para su inmediata ocupación, exigiéndose, además, autorización administrativa; mientras que las segundas se ofrecen con independencia de sus condiciones de mobiliario, equipo, instalaciones y servicios y sin necesidad de licencia.

REALA, Nueva Época, - N. ${ }^{\circ}$ 5, enero-junio 2016 - ISSN: 1989-8975 - DOI: 10.24965/reala.voi5.10350 
Como ya hemos hecho mención anteriormente, el alojamiento colaborativo no es exclusivo de nuestro país, antes al contrario; aquí ha llegado de forma tardía una vez que se ha instalado de forma definitiva en todos los destinos turísticos a nivel mundial. En concreto, la plataforma virtual de alojamiento turístico que mayores problemas ha acarreado es AirBnb por ser, sobre todo, la que dispone de un mayor número de usuarios en todo el mundo. Pero si bien su establecimiento ha sido sencillo al tratarse de una empresa que opera online, la implantación de su actividad no lo ha sido tanto al no encontrar acomodo en la normativa existente en ningún país, lo que, en realidad, es una consecuencia natural de los procesos económicos disruptivos en los que el Derecho no alcanza a acompañar de forma paralela a la ordenación de la sociedad debido a las vertiginosas posibilidades tecnológicas $^{44}$. En este caso, la economía colaborativa no supone un avance tecnológico en sí misma pero está propiciada por el desarrollo de las TIC, sin que en su evolución haya encontrado un soporte jurídico eficaz y, sobre todo, coetáneo. Por esta razón, esta nueva modalidad de alquileres turísticos ha funcionado desde su implantación sin estar sometida a normativa alguna. Pero una vez que la pesada maquinaria jurídica se ha puesto en marcha esta situación de limbo jurídico ha comenzado a desaparecer. Numerosos países han optado por legalizar esta nueva oferta turística que, poco a poco, comienza a convertirse en oferta reglada; encontramos, así, legislaciones que son completamente favorables a estas plataformas virtuales, como las establecidas en Londres o Ámsterdam, frente a otras que han optado por poner trabas a esta actividad en aras de la protección de los alquileres de larga duración, como Berlín o París.

En España las Comunidades Autónomas han seguido esta misma tendencia normativa al regular los alquileres vacacionales gestionados a través de plataformas virtuales como AirBnb. Y es que el núcleo principal de responsabilidades sobre el turismo se residencia en nuestras Comunidades Autónomas, a tenor de la competencia exclusiva que asumieron en sus respectivos Estatutos de Autonomía partiendo de la posibilidad abierta en el artículo 148.1.18 CE, sobre promoción y ordenación del turismo en sus respectivos ámbitos territoriales y de la ausencia de reserva competencial específica en la materia a favor del Estado en el artículo 149.1 CE. En consecuencia, todas ellas ostentan el mismo grado de competencia que alcanza por entero a la regulación jurídica del turismo y a las facultades ejecutivas inherentes ${ }^{45}$, que han ejercitado, de hecho, aprobando leyes ordenadoras del turismo que se han convertido en verdaderas normas cabecera del ordenamiento turístico autonómico.

Pues bien, como veremos, la regulación a la que nuestras Comunidades han sometido a esta nueva forma de alquileres turísticos es muy similar, con análogo contenido aunque distinta forma. Si bien hasta 2016 esta normativa era únicamente la que regulaba la cesión de uso de viviendas completas, ya que ninguna Comunidad permitía el arrendamiento por estancias o habitaciones, Andalucía se ha desmarcado con el Decreto 28/2016, de 2 de febrero, de viviendas con fines turísticos. Las previsiones apuntan a que las siguientes normas AirBnb friendly serán aprobadas en Barcelona y Valencia.

\subsubsection{El estado de la cuestión fuera de nuestras fronteras}

La ausencia de normativa en cuanto al alojamiento colaborativo no se limita a nuestro país. En efecto, la economía colaborativa ha llegado a España después de enraizar con fuerza en Estados Unidos y en otros muchos países de Europa. Y en todos ellos, la polémica se desató por la plataforma AirBnb. Al igual que ha sucedido con Uber ${ }^{46}$, el vacío legal existente ante la actividad que desarrolla ha hecho saltar las alarmas del sector hotelero y de las Administraciones Públicas. Parece, sin embargo, que este estado de indefinición del que esta plataforma virtual se ha beneficiado hasta el momento toca a su fin ya que numerosos países -entre los que, de momento, no se encuentra España- han procedido a regular la situación de estas plataformas virtuales, estableciendo de forma detallada cuáles son las obligaciones que derivan de la actividad que desempeñan. Así, en Estados Unidos son numerosos los Estados que han establecido normativa al efecto a lo largo de 2014 y 2015, orientada, por un lado a legalizar el alquiler de la propia vivienda y, por otro a que estas plataformas sirvan de cauce para el cumplimiento de las obligaciones urbanísticas derivadas del alquiler vacacional por los particulares a los que pone en contacto ${ }^{47}$.

44 BoIX PALOP, A., "De McDonald's a Google: la ley ante la tercera revolución productiva”, Teoría y Derecho: Revista de Pensamiento Jurídico, op. cit., p. 128.

45 BERMEJO VerA, J., Derecho Administrativo, parte especial, Madrid, Civitas, 2009, p. 1003.

46 Sobre este fenómeno, véase el estudio de DOMÉNECH PASCUAL, G., "La regulación de la economía colaborativa (Uber contra el taxi), Revista CEF Legal, op. cit.

47 Ya es legal el alquiler de la vivienda habitual a través de AirBnb en Portland, Washington DC; Chicago y San José de California. En San Francisco, hasta 2014, era ilegal alquilar una vivienda menos de 30 días si no se disponía de un permiso especial. Pero desde octubre de ese mismo año se ha legalizado el alquiler de la vivienda habitual siempre que se haga por períodos inferiores a 90 días y que el propietario no conviva en la misma vivienda con el turista. Debe solicitarse autorización administrativa al City Planning Department y pagarse la tasa turística (14\% del importe del alojamiento), que ha de ser cobrada directamente por AirBnb para remitirla posteriormente en nombre del usuario. En Nueva York, el mayor problema se encuentra en que no es legal alquilar un inmueble por un período inferior a 30 días, salvo que las propietarias y propietarios también convivan en la misma vivienda. Véase JEFFERSON-JONES, J., "AirBnb and the Housing Segment of the Modern "Sharing

REALA, Nueva Época, - N. ${ }^{\circ}$ 5, enero-junio 2016 - ISSN: 1989-8975 - DOI: 10.24965/reala.voi5.10350 
En Europa también son numerosos los países que han optado por legalizar la situación de estos alquileres por habitación y, por ende de las plataformas virtuales en las que se anuncian, comenzado por AirBnb. En estos dos últimos años, han aparecido normas específicas en aquellas ciudades donde el turismo es uno de los principales motores de la economía. Ámsterdam fue la pionera en adoptar una AirBnb friendly legislation ${ }^{48}$, permitiendo a las propietarias y propietarios realizar este tipo de alquileres turísticos de corta duración en la vivienda habitual, sin que se permita en segundas residencias. Con ello se trataba de facilitar el alojamiento a quienes debían permanecer en esta ciudad varias noches por motivos profesionales. Gracias a los short-term rentals ${ }^{49}$, regulados por la Housing Allocation Act (Huisvestingswet) y por la Regional Housing Regulation, se permite esta cesión de uso del inmueble o de un barco -sí, también pueden alquilarse por camarote si constituyen residencia habitual- siempre que sea de, al menos, siete noches; si el número de noches es menor, no es factible un alquiler privado y necesariamente ha de hacerse en un hotel o en un bed \& breakfast. Es lo que se conoce como la controvertida seven-day rule. El intercambio de casas -home exchange-, se sigue permitiendo y no entra dentro de este supuesto siempre que no medie contraprestación.

París, por su parte, también ha legalizado estas plataformas virtuales gracias a la Loi ALUR/Duflot 2015 (Accès au Logement et urbanisme rénové $)^{50}$. El sistema anterior establecía que los arrendamientos de segunda vivienda eran legales cuando el plazo era superior a 1 año (a 9 meses en caso de estudiantes). En 2009, comenzó a aplicarse una legislación que prácticamente nunca había sido utilizada (L. 632-1 y L.632-7 Construction Code) que obligaba a los propietarios que quisieran alquilar estas segundas viviendas por períodos inferiores al año a solicitar una licencia si querían cambiar la condición de su apartamento -de residencial, a no residencial y comercial-, lo que requería un proceso largo y costoso. La vivienda habitual, sin embargo, sí podía alquilarse mientras el propietario estuviera fuera de la misma por vacaciones, etc. sin necesidad de autorización especial; los intercambios de vivienda también estaban permitidos.

Con la Loi ALUR se llevaron a cabo importantes modificaciones en materia de alquiler de vivienda para hacer frente a la situación de alquileres ilegales que se estaba generalizando en la ciudad ${ }^{51}$ y que había provocado una disminución alarmante de la oferta de viviendas en venta y de alquileres de larga duración. Los cambios producidos por esta Ley de 2015 permiten que se lleven a cabo arrendamientos de temporada -location saisonniêre- pero sólo de hasta 90 días. Cuando se trata de viviendas no habituales en la ciudad, el período mínimo de alquiler es de un año y si se quiere arrendar por períodos más cortos, es necesario registrar la vivienda como propiedad con fines comerciales, poniendo en conocimiento del Ayuntamiento que el destino del inmueble será el alquiler; si bien en caso de barrios concretos de más de 200.000 habitantes se ha de solicitar una autorización administrativa y también a la junta de propietarias y propietarios del inmueble. Además, si los beneficios obtenidos superan los 32.600 euros/año, se someten a un régimen especial -imposición de beneficios industriales y comerciales, BIC o microBIC-. En este supuesto no cabe el alquiler por habitaciones, sólo cabe la cesión de uso de la vivienda completa. Las sanciones por los arriendos ilegales en las segundas residencias pueden superar los 25.000 euros.

En el caso de la vivienda habitual, si se alquilan habitaciones, se trata de habitaciones de invitados -chambres d'hôtes-, según el artículo L324-3 de la Loi n. ${ }^{\circ}$ 2006-437 de 14 de abril de 2006, por lo que no se pueden alquilar más de 5 habitaciones de la vivienda al mismo tiempo sin que se pueda albergar a más de quince personas, por un período máximo de cuatro meses al año. Y hay que declarar esta situación al ayuntamiento. Se permite, asimismo, el subarriendo pero

Economy”: Are Short-Term Rental Restrictions an Unconstitutional Taking?”, Hastings Constitutional Law Quarterly, n. ${ }^{\circ}$ 3, pp. 457-576. También KASSAN J., Orsi, J., "The legal landscape of the sharing economy”, Journal of Environmental and Litigation, n. ${ }^{\circ} 27,2012$, pp. 1-20.

48 Aun así, esta plataforma no está exenta de obligaciones, como el pago de la tasa turística y también a proporcionar a los anfitriones información clara sobre la normativa legal y aquellos deben declarar que la entienden y cumplen antes de publicar un anuncio en su página web.

49 Existen, además, muchos otros requisitos que han de ser necesariamente observados para poder llevar a cabo estas cesiones de uso de habitación; así, es necesario solicitar licencia administrativa a la City District Office, cuyo coste rondaba los 800 euros en 2012 , aunque desde 2014 se ha suspendido la concesión de nuevas licencias por haberse excedido del 10 por cien de viviendas privadas que ofrecían este servicio. Por el momento, sólo las viviendas de nueva construcción en determinados distritos pueden solicitar la licencia. Además, las propietarias y propietarios de la vivienda no pueden permanecer en la misma durante el tiempo en el que dure la cesión de uso. El número máximo de pernoctantes que pueden permanecer en la vivienda cuando esta sea cedida a turistas es de cuatro. La duración mínima, como hemos visto, es de siete noches y sólo caben estas cesiones por un máximo de sesenta días al año. También se debe pagar la tasa turística que es de un $5,5 \%$ del total de cada estancia. En el caso de AirBnb, es la propia plataforma la que la cobra y remite a la Administración en nombre del usuario. Véase OSKAM, J., BOSWIJK, A., "AirBnb: the future of networked hospitality businesses", Journal of Tourism Futures, n. ${ }^{\circ} 1,2016$, pp. 22-42. También HeIDE, D., PETERS, K.B.M., “AirBnb als hulpmiddel voor spreiding van toerisme in Amsterdam?”, Vrijetijdstudies, n. ${ }^{\circ} 2,2015$, pp. 9-22.

50 Se trata de la Loi n. ${ }^{\circ} 2014-366$ du 24 mars 2014 pour l'accès au logement et un urbanisme rénové, disponible online en el sitio: https://www.legifrance.gouv.fr/affichTexte.do?cidTexte=JORFTEXT000028772256\&dateTexte=20160515.

51 Ya en 2011, al menos dos terceras partes de los pisos que se arrendaron por habitación en París con finalidad turística no constituían vivienda habitual de su propietario, por lo que cerca de 20.000 personas fueron responsables de infracciones administrativas por este motivo. En 2014, este número ascendió a los 30.000. Véase DEVAUX, C., L'habitat participatif: De l'initiative habitante à l'action publique, Paris, Presses Universitaires Rennes, 2015. También LEFEBVRE, N., “Destination et expériences: l'adaptation de l'offre touristique de Paris aux nouvelles attentes”, Annales des Mines. Réalités industrielles, n. ${ }^{\circ}$ 3, 2015, pp. 58-62. Asimismo, PÉRINET-MARQUET, H., "Accès au logement et urbanisme rénové. Loi ALUR du 24 mars 2014", Semaine juridique, n. ${ }^{15}$, 2014, pp. 709-712. Y FERRARY, N., "Les nouvelles formes de tourisme collaboratif: una demande en pleine expansion”, Annales des Mines. Réalités industrielles, n. 3, 2015, pp. 50-53. 
con autorización del propietario si el contrato se realiza bajo la vigencia de esta nueva ley. El propietario está obligado a declarar los beneficios obtenidos. En el caso de que esta cesión de uso se realice a través de la plataforma AirBnb, ésta viene obligada a recabar el importe de la tasa turística -0,83 euros por persona/noche- en nombre de sus propietarios.

En Hamburgo, este tipo de alquiler vacacional es legal desde 2013, siempre que se trate de primera residencia y su propietaria o propietario estén ausentes de forma temporal, sin que sea necesario solicitar licencia ${ }^{52}$. En Berlín, sin embargo, ha entrado en vigor una nueva normativa ${ }^{53}$-Zweckentfremdungsverbot- que prohíbe los arrendamientos de corta duración de viviendas completas sin licencia desde 2016, aunque no los de habitaciones. Estas drásticas medidas son fruto de la falta de oferta de inmuebles en compra y alquiler de larga duración,

También Reino Unido se ha unido a esta nueva tendencia en materia de turismo colaborativo mediante la aprobación de un Plan de medidas de apoyo a la economía colaborativa, para convertirse en Global Centre for the Sharing Economy54. La normativa existente hasta el momento -Greater London Council (General Powers) Act, 1973prohibía el uso de viviendas de uso residencial para el alojamiento temporal inferior a tres meses (art. 25) para proteger la oferta de alquileres en Londres por considerarlo un cambio de uso. Para ello, debía solicitarse licencia. Esta prohibición no resultaba de aplicación fuera de la ciudad de Londres. Con el anuncio de los Juegos Olímpicos de 2012, comenzaron a publicitarse numerosas viviendas londinenses en los portales de alquileres de corta duración, lo que suponía a todas luces una transgresión masiva del artículo 25 de la Ley de 1973 que, a pesar de estar totalmente obsoleta, no había sido derogada. A la vista de la situación, el Department for Communities and Local Government ha optado por una política de modernización cuyo propósito es incrementar la competitividad en los precios del alojamiento turístico, además de reducir el número de viviendas vacías. De este modo se permite a los londinenses participar en la economía colaborativa para que puedan alquilar sus viviendas durante cortos períodos de tiempo -short-term use of residential property- sin necesidad de solicitar autorización administrativa, con la misma libertad y flexibilidad que el resto del país.

Gracias a la Deregulation Act 2015, los ciudadanos de Londres pueden beneficiarse de las ventajas de la economía colaborativa y alquilar sus viviendas a los turistas por cortos períodos de tiempo ${ }^{55}$. Véase la Housing and Development (chapter 20) 44-45, short term-use of London accommodation: relaxation of restrictions \& power to relax restrictions ${ }^{56}$, que ha establecido una excepción al art. 25 de la Greater London Council (General Powers) 1973 Act, al señalar que el alojamiento temporal en la ciudad Londres no supone un cambio de uso ${ }^{57}$, siempre que se cumplan dos requisitos: que el número de noches de alquiler temporal no exceda de noventa al año -tres meses- y que quien proporcione el alojamiento será responsable de pagar la council tax. Las sanciones por el incumplimiento de estas cautelas ascienden a la cantidad de 20.000 libras $^{58}$

\subsubsection{El alquiler turístico de viviendas completas en España}

En cuanto se refiere a las cesiones de uso de viviendas con fines turísticos realizadas a través de las plataformas virtuales como AirBnb, es evidente que se trata de una realidad social que existe y va en aumento en los sitios de mayor afluencia turística, por lo que no es dable obviar su regulación, aunque esta sea tardía -por la ya referida poca capacidad de reacción de nuestro ordenamiento jurídico- e incompleta, dado que de momento se

52 La Ley de 21 de mayo de 2013, que ha legalizado este tipo de estancias vacacionales en Hamburgo. Disponible online en: http://www. landesrecht-hamburg.de/jportal/portal/page/bshaprod.psml?showdoccase=1\&st=Ir\&doc.id=jlr-WoPflGHArahmen\&doc.part=X.

53 Puede consultarse esta norma online en http://www.parlament-berlin.de/ados/17/IIIPlen/vorgang/d17-1057.pdf.

54 En septiembre de 2014 el Gobierno británico encargó a D. Wosskow, de la empresa Love Home Swap, que realizase un informe independiente sobre la economía colaborativa. Este informe fue publicado en noviembre, recogiendo diversas recomendaciones sobre cómo el Reino Unido podía convertirse en el centro mundial de la economía colaborativa (puede consultarse este informe en: https://www.gov.uk/government/publications/unlocking-the-sharing-economy-independent-review). Posteriormente, el Gobierno publicó la respuesta a esta revisión independiente y las recomendaciones formuladas al respecto (puede consultarse online en: https://www.gov.uk/government/uploads/system/ uploads/attachment_data/file/414111/bis-15-172-government-response-to-the-independent-review-of-the-sharing-economy.pdf.).

El Gobierno británico se ha mostrado completamente a favor de la economía colaborativa, llegando a afirmar «this government response formally lays down the first steps to making the UK the sharing economy's natural home». Además, véase QUATTRONE, G., PROSERPIO, D., QUERCIA, D., CAPRA, L., MUSOLESI, M., “Who benefits from the «Sharing» Economy of AirBnb?”, International World Wide Web Conference. WWW, n. 16, 2016, pp. 1385-1394.

55 Esta Deregulation Act 2015 se encuentra disponible online para su consulta en http://www.legislation.gov.uk/ukpga/2015/20/contents/enacted/data.htm. Puede consultarse, asimismo, la guía sobre alquiler de estancias en viviendas que proporciona el gobierno (Rent a room in your home) en https://www.gov.uk/rent-room-in-your-home/print.

56 Puede consultarse online en http://www.publications.parliament.uk/pa/bills/cbill/2014-2015/0005/amend/pbc0051606a.pdf.

57 Sobre los usos turísticos del suelo y sobre planificación turística véase BouAZZA ARIÑo, O., La planificación territorial en Gran Bretaña. Especial referencia al sector turístico, Cizur Menor, Civitas Thomson-Reuters, 2009, pp. 57 y ss.

58 VARA ARRIBAS, G., STEIBLE, B., BONDT, Informe "Cost of non-Europe in the sharing economy: legal aspectsn (PE558.777) a solicitud del Impact Assessment Unit of the Directorate for Impact Assessment study under no. and is republished here by EIPA with the kind permission of the European Parliament".

REALA, Nueva Época, - N. ${ }^{\circ}$, enero-junio 2016 - ISSN: 1989-8975 - DOI: 10.24965/reala.voi5.10350 
ha parcheado por medio de normas que no atienden a la totalidad de las modalidades de alojamiento ofertadas por estas plataformas colaborativas, como veremos más adelante. Pues bien, todas las Comunidades Autónomas cuentan con normativa propia en esta concreta cesión de uso turístico, ya que tras la reforma de la LAU estos contratos están sometidos a la legislación sectorial correspondiente, que es la autonómica por las razones ya apuntadas. Así, de forma general se ha optado por legalizar esta figura mediante la creación de decretos turísticos ad hoc; aunque la excepción la constituye Cantabria al permitir que sea el propietario quien decida si quiere gestionar su arrendamiento a través de la Ley de Arrendamientos Urbanos o a través de la normativa sectorial -Decreto 19/2014, de 13 de marzo, de modificación del Decreto 82/2010, de 25 de noviembre, que regula los establecimientos de alojamiento turístico extra-hotelero ${ }^{59}$.

Estas nuevas formas de alojamiento se denominan viviendas de uso turístico (Madrid, Aragón), viviendas con fines turísticos (Andalucía), viviendas turísticas (Valencia), habitatge d'ús turístic (Barcelona) ${ }^{60}$ o viviendas vacacionales (Canarias) a aquellos pisos, apartamentos o casas que, amueblados y equipados en condiciones de uso inmediato, se comercializan y promocionan en canales de oferta turística ${ }^{61}$ para ser cedidos en su totalidad con fines de hospedaje turístico a cambio de un precio. Las principales diferencias con el denominado «alojamiento turístico» ${ }^{62}$ son, por un lado, la habitualidad en la prestación de este servicio ya que las empresas de alojamiento se dedican de forma profesional y habitual a esta actividad y, por otro, que no se trata de un establecimiento abierto al público. Partiendo de esta definición de vivienda turística, veremos que la normativa autonómica no difiere en demasía en cuanto a la regulación de esa modalidad de alojamiento colaborativo cuando se trata de cesión del inmueble al completo, que es el primero de los requisitos que se establece por todas las Comunidades Autónomas. El segundo es que no cabe el arrendamiento con fines turísticos de la residencia habitual.

Una de las cuestiones que mayores problemas de interpretación ha acarreado es la que se refiere a la manera de ofertar este alojamiento ya que, en general, se establece que debe hacerse a través de canales de oferta turística, sin que quepa la publicidad directa por parte del propietario ${ }^{63}$. Así las cosas, Baleares fue pionera al aprobar la primera ley turística que regulaba este tipo de estancias vacacionales ya en 2005, gracias a la Ley de comercialización de estancias turísticas en viviendas (hoy derogada por la Ley 8/2012, de 19 de julio, del Turismo de las Illes Balears ${ }^{64}$ ). Esta Ley de 2005 permitía ofertar estas estancias siempre que su publicidad fuera gestionada exclusivamente a través de los canales de comercialización turística establecidos. También Valencia exige que la cesión de uso sea hecha a través de internet, o de gestoras u operadoras turísticas para poder ser reguladas a través del Decreto 92/2009, de 3 de julio y del Decreto 206/2010, de 3 de diciembre. Para poder ofertarse de forma directa a través del propietario de la vivienda, éste debe dedicarse a la prestación de servicios propios de la industria hotelera, situación que no se da en Barcelona, ya que las HUT pueden ser comercializadas a través de canales de oferta turística, pero también por su propietario. En Aragón, el Decreto 80/2015, de 5 de mayo, sobre viviendas de uso

59 De optar por esta última, el propietario puede anunciar su alquiler vacacional a través de cualquier medio siempre que utilice los adjetivos «vacacional», «turístico», etc. Si por el contrario se optare por la aplicación de la LAU, el propietario debe suscribir un contrato de arrendamiento con cada alquiler que efectúe, sin que quepa la posibilidad de publicitar este alquiler en canales de oferta turística. En ningún caso se permite el alquiler de la vivienda por estancias.

60 Es el Decreto 159/2012, de 20 de noviembre, de establecimientos de alojamiento turístico y viviendas de uso turístico el que reconoce esta nueva categoría de vivienda (HUT).

61 Sin duda, una de las grandes preocupaciones que ha promovido este movimiento normativo ha sido la necesidad de proteger al consumidor para que disfrute de servicios de calidad. Ya que igual de importante que el producto turístico en sí es el canal a través del que se promociona. Uno de los motivos que se apunta es que el consumidor pueda pedir responsabilidades a la agencia de viajes a la que normalmente tiene cerca frente a la dificultad y coste que supondría reclamar a un proveedor, por ejemplo, de alojamiento en destino. Esto es así gracias a la Directiva (UE) 2015/2302 del Parlamento Europeo y del Consejo, sobre viajes combinados. Véase FERNÁNDEZ FLORES, R., “La naturaleza jurídica de los market-place”, disponible online en la página web de la Federació d’Hostaleria de Lleida: http://www.horecalleida.es/wp-content/ uploads/Naturaleza-Juridica-de-los-marketplaces.pdf.

62 De acuerdo a la Decisión de la Comisión 99/34/CE, de 9 de diciembre de 1998, sobre los procedimientos de aplicación de la Directiva 95/57/CE del Consejo sobre la recogida de información estadística en el ámbito del turismo (DOCE n. ${ }^{\circ} \mathrm{L}$ 9, de 15-1-99), un alojamiento turístico es cualquier estructura empresarial que presta un servicio de alojamiento regularmente. El alojamiento colectivo es aquel que constituye una actividad empresarial regular, que consiste en ofrecer al turista la posibilidad de pernoctar en una habitación u otro espacio acondicionado para el alojamiento, siendo su capacidad mayor a un determinado número de camas. Mientras que define el alojamiento privado por la particularidad añadida de que se trata de alojamientos que no son empresas convencionales y que disponen de una capacidad limitada.

63 Uno de los motivos que se apunta es la facilidad que existe para reclamar ante la agencia de viajes, a la que normalmente tiene cerca, frente a la dificultad y coste que supondría reclamar a un proveedor, por ejemplo, de alojamiento en destino. Esto es así gracias a la Directiva (UE) 2015/2302 del Parlamento Europeo y del Consejo, sobre viajes combinados (FERNÁNDEZ FLORES, R., "La naturaleza jurídica de los marketplace", disponible online en la página web de la Federació d'Hostaleria de Lleida, http://www.horecalleida.es/wp-content/uploads/NaturalezaJuridica-de-los-marketplaces.pdf).

64 En realidad, la primera norma en la materia data de 1984 (Ley 2/1984, de 12 de abril), que pretendía reaccionar contra el gran número de apartamentos clandestinos existentes en Baleares. Sobre esta materia, véase BLASCO ESTEVE, A., "Planificación y gestión del territorio turístico de las Islas Baleares", en MelcosA ARcos, F.J. (Ed.), Derecho y turismo, Salamanca, Ediciones Universidad de Salamanca, 2004 , pp. 385-436, p. 413. 
turístico, establece la presunción de que se trata de viviendas turísticas siempre que se den dos requisitos, como son que se haya promocionado o comercializado a través de canales de oferta turística y, además, que se ceda por un período igual o inferior a un mes por usuario. Este requisito de tiempo no se da, sin embargo, en Andalucía, que considera viviendas turísticas aquellas que se ceden de forma habitual y con fines turísticos a cambio de precio, considerándose la habitualidad inherente a la oferta en canales turísticos, según Decreto 28/2016, de 2 de febrero, de viviendas con fines turísticos.

Por otro lado, en cuanto al número de pernoctas que puede llevarse a cabo en estas viviendas turísticas, las Comunidades Autónomas han establecido períodos relativamente amplios, pero siempre estableciendo pernocta máximas, como las 31 noches de Barcelona ${ }^{65}$ y Aragón ${ }^{66}$, o los dos meses de Andalucía ${ }^{67}$. El período más corto había sido establecido en Madrid, con una limitación temporal de alquilar por períodos superiores a 5 días ${ }^{68}$, pero dos sentencia del Tribunal Superior de Justicia de mayo de 2016 han declarado nula dicha limitación por suponer una restricción de la competencia no justificada ${ }^{69}$. En Canarias se ha optado por no establecer plazos a este respecto ${ }^{70}$.

Sobre los requisitos a nivel administrativo, la mayor parte de las Comunidades ha optado por la presentación de la declaración responsable como autorización inicial de funcionamiento de esta actividad (Madrid, Valencia, Andalucía o Aragón), no así en Cataluña, en la que las propietarias y propietarios deben presentar una comunicación previa al Ayuntamiento competente. A continuación, es necesaria la inscripción de la vivienda en el Registro correspondiente; en Madrid es el Registro de Empresas Turísticas; en Cataluña y Andalucía es el Registro de Turis$\mathrm{mo}^{71}$. En Valencia es el Registro de empresas, establecimientos y profesiones turísticas de la Comunidad Valenciana -Decreto 75/2015, de 15 de mayo-; de hecho, si la vivienda turística careciese de número de registro no puede publicitarse, ya que es obligatorio incluir este número en toda publicidad de la vivienda. Su incumplimiento será sancionado con multa de hasta 90.000 euros y serán responsables solidarios no sólo las propietarias y propietarios de la vivienda sino también los titulares de los canales de publicidad o comercialización.

Pero no son estos los únicos requisitos necesarios para poder ofertar una vivienda turística; en determinadas Comunidades Autónomas el turista está obligado al pago de la tasa turística, que suele incluirse en el precio del alojamiento cuando se trata de hospedaje reglado. Así, en Barcelona, estas cesiones de uso no eximen del pago del impuesto sobre la estancias en establecimientos turísticos ${ }^{72}$, que habrá de hacerse al final de cada estancia con la entrega previa de la factura por parte del propietario de la vivienda, que está obligado a presentar posterior liquidación ante la Agencia Tributaria. Se exige, asimismo, disponer de cédula de habitabilidad, sin que el alquiler turístico pueda excederse del número de plazas indicadas en la misma. Pero también deben cumplirse las condiciones técnicas y de calidad exigibles a todas las viviendas, además de estar amuebladas de forma suficiente y disponer de los enseres y aparatos necesarios para su inmediata ocupación, así como mantenerse en perfectas condiciones de higiene. En Valencia deben disponer, además, de la licencia de primera ocupación. En esta misma Comunidad se ha planteado un problema adicional, como es el de la necesidad o no de licencia ambiental prevista en la Ley 6/2014, de 25 de julio, de prevención, calidad y control ambiental de actividades de la Comunidad Valenciana. El Decreto 206/2010, de 3 de diciembre, por el que se modifican los decretos reguladores del alojamiento turístico, establece que, para la puesta en funcionamiento del alojamiento turístico se requiere (art. 24) que quede constancia de que el solicitante tiene a su disposición el certificado de compatibilidad urbanística y que cuenta con las autorizaciones exigidas -urbanísticas, ambientales y de apertura-. Esta circunstancia ha sido aprovechada por la Administración valenciana para paralizar esta actividad de cesión turística cuando no se hubiese solicitado

65 Artículo 66.3, Decreto 159/2002, de 20 de noviembre.

66 Artículo 2.c, Decreto 80/2015, de 5 de mayo.

67 Artículo 1.2.b, Decreto 28/2016, de 2 de febrero.

68 Decreto 79/2014, de 10 de julio, de apartamentos turísticos y viviendas de uso turístico en la Comunidad de Madrid.

69 Véanse las Sentencia de la Sala de lo Contencioso-Administrativo, Sección 8. ${ }^{\text {, }}$ del TSJ de Madrid, de 31 de mayo de 2016 (Rec. 1165/2014, Pte. Guillo Sánchez Galiano), con ocasión del recurso planteado por ALOJA Madrid, y de 31 de mayo de 2016 (Rec. $65 / 2015)$ a resultas del recurso interpuesto por la CNMC. Por lo que respecta al inciso concreto del artículo 17.3 del Decreto madrileño, ambas sentencias establecen que la limitación del período de pernocta es contraria a diversos preceptos constitucionales, crea un obstáculo a la competencia efectiva de los mercados en los términos previstos en el art. 5.4 de la mencionada Ley 3/2013, conculca la Directiva 2006/123/CE del Parlamento Europeo y del Consejo, de 12 de diciembre de 2006, relativa a los servicios en el mercado interior y la Ley de transposición de la misma, Ley 17/2009, de 23 de noviembre, sobre el libre acceso a las actividades de servicio y su ejercicio, así como también las previsiones de la Ley $20 / 2013$, de 9 de diciembre, de garantía para la unidad de mercado.

70 Artículo 2.d, Decreto 113/2015, de 22 de mayo.

71 En cuanto a la responsabilidad derivada de la infracción de la normativa sectorial turística, de vivienda, consumo o municipal, el art. 72 del citado Decreto establece la solidaridad entre el propietario y el tercero que gestione el alquiler de temporada.

72 Establecido por la Ley 5/2012, del 20 de marzo, de medidas fiscales, financieras y administrativas, la tasa turística es un tributo propio de la Generalitat de Catalunya que grava la singular capacidad económica de las personas físicas que se pone de manifiesto con el alojamiento turístico, con o sin pernoctación. Aparece regulado en el Decreto 129/2012, de 9 de octubre, por el que se aprueba el Reglamento del impuesto sobre las estancias en establecimientos turísticos. Su importe en Barcelona es de o'65 euros por noche.

REALA, Nueva Época, - N. ${ }^{\circ}$ 5, enero-junio 2016 - ISSN: 1989-8975 - DOI: 10.24965/reala.voi5.10350 
dicha licencia, midiendo con el mismo rasero la oferta turística reglada y la no reglada. Los tribunales valencianos, sin embargo, se han desmarcado de esta tendencia al establecer que esta licencia no es un requisito necesario ${ }^{73}$, por no encontrar indicios de potencial afección al medio ambiente cuando se trata de cesión de uso de viviendas turísticas.

\subsubsection{El alquiler turístico de habitaciones en viviendas en España}

Si bien todas las Comunidades Autónomas, en desarrollo de sus competencias en esta materia, han regulado la cesión de uso de viviendas con fines turísticos, hasta este mismo año ninguna había previsto el supuesto de alquiler de habitaciones en viviendas particulares. No entendemos la razón de esta imposibilidad, aunque intuimos que, como ha sucedido históricamente, poner en marcha la pesada maquinaria jurídica de regulación de nuevas instituciones lleva su tiempo y, además, produce temor, por la innovación que suponen frente a lo tradicional y conocido. Ese es el problema; estamos acostumbrados a analizar la realidad y a actuar sobre ella a partir de ideas antiguas que tan bien funcionaron, porque aportan seguridad ${ }^{74}$. Sin embargo, debemos pensar que muchas de las categorías turísticas que ahora nos resultan tradicionales también fueron novedosas en algún momento. La evolución impone la incorporación de nuevas modalidades turísticas acordes a las demandas actuales, que si bien ahora son las relativas al alojamiento colaborativo, en los años sesenta y setenta fueron otras como el agroturismo, o más recientemente el turismo activo y de aventura, las categorías que se han incorporado a nuestra oferta turística y han sido adecuadamente reguladas por nuestro ordenamiento.

Recordemos que también el turismo rural nació del amplio fenómeno de concienciación y reivindicación ecológica que viven las sociedades avanzadas y altamente urbanizadas, potenciado por los problemas de congestión, transformación y degradación de muchos espacios litorales dedicados a la recepción del turismo masivo ${ }^{75}$. Este nuevo turismo rural también supuso una serie de innovaciones importantes en la estructura del mercado turístico español, incorporando nuevos destinos al mapa turístico, creando nuevas figuras de alojamiento. Así pues, esta actividad ha sido convenientemente ordenada por las CCAA en virtud de sus competencias exclusivas, sin que en ningún caso esta categoría haya decaído o dejado de existir; antes al contrario, se le ha otorgado un régimen jurídico que otorga garantías en cuanto a la calidad de la prestación de servicios para el usuario, lo que redunda en una mejora del turismo a nivel global. Lo mismo ha sucedido con el resto de categorías turísticas ya que es consustancial a la propia naturaleza del Derecho, como fenómeno y como producto, ir proporcionando una respuesta adaptada a las necesidades sociales y a su evolución.

Suponemos que han sido estas las razones que han llevado a que la práctica totalidad de las Comunidades Autónomas hayan optado por regular tan sólo el alquiler turístico de viviendas completas, prohibiendo la cesión de uso de habitaciones para fines turísticos. En Baleares sólo se permitía la comercialización de viviendas completas, especificando que no puede darse en ningún caso coincidencia de diversas personas que hubieran formalizado diferentes contratos de alojamiento. Por su parte, el Decreto 80/2015, de 5 de mayo, sobre viviendas de uso turístico en Aragón, tampoco permite alquilar habitaciones, siendo responsables de las infracciones la propiedad y, en su caso, los gestores de las viviendas y los canales de distribución o promoción de la oferta turística. En Canarias, el Decreto 113/2015, de 22 de mayo, que aprueba el Reglamento de viviendas vacacionales, prohíbe de forma expresa la cesión por habitaciones, cuyo incumplimiento es sancionable.

Tampoco se permite en Comunidad Valenciana, ya que los referidos Decretos de 2009 y 2010 no regulan el supuesto de alquiler vacacional de viviendas por habitación. Y ello a pesar de haber supuesto una importante modernización de la normativa referente a la planta hotelera, necesaria en todo caso y acorde a las transformaciones acaecidas con el transcurso del tiempo -recordemos que la Ley valenciana de turismo ha cumplido veinte años de vida-, como la inmersión en la era digital que atraviesa la sociedad. Así las cosas, a pesar de que su propia Exposición de Motivos establezca la necesaria readaptación de la planta alojativa a las exigencias de un mercado cambiante, este tipo de estancia vacacional no es encuadrable en la oferta turística regulada en Valencia, dado que los cedentes de los inmuebles no suelen ser empresarios hoteleros, ni tampoco las características del inmueble son las propias del sector hotelero. En esta Comunidad, a pesar de que la situación no reviste la gravedad de Cataluña, también comienza a ser preocupante; según datos de Exceltur, durante el primer trimestre de 2015, casi 23.000 turistas se alojaron en establecimientos reglados, pero otros casi 15.000 lo hicieron a través de plataformas virtuales

73 Así lo ha dejado claro una reciente Sentencia del Juzgado de Contencioso-Administrativo n. ${ }^{\circ} 6$ de Valencia, de 27 de abril de 2016 (PO $284 / 2015)$, al establecer que no encuentra diferencia alguna entre la cesión de uso remunerada y habitual de viviendas turísticas y los contratos civiles de arrendamiento de vivienda sujetos a la LAU en cuanto a la potencial afección al medio ambiente.

74 BoIx PALOP, A., “De McDonald's a Google: la ley ante la tercera revolución productiva”, Teoría y Derecho: Revista de Pensamiento Jurídico, op. cit., p. 135

75 PÉREZ FERNÁNDEZ, J.M., Régimen jurídico del turismo rural, Madrid, FITUR, 2001, p. 16.

REALA, Nueva Época, - N. ${ }^{5}$, enero-junio 2016 - ISSN: 1989-8975 - DOI: 10.24965/reala.voi5.10350 
en habitaciones de viviendas. Es evidente la necesidad de una normativa que otorgue regulación a estas concretas cesiones de uso turístico, al igual que ya se hizo con los arrendamientos turísticos de viviendas. Las últimas noticias en este año 2016 apuntan a un diálogo entre el Gobierno valenciano y las plataformas virtuales para establecer la hoja de ruta en el establecimiento y cumplimiento de la legislación autonómica en Valencia.

El caso más polémico a todas luces es el de Barcelona, en el que la falta de ordenación de esta concreta figura ha avivado el conflicto público, enrareciendo la convivencia entre ciudadanos y turistas ${ }^{76}$. Las primeras medidas jurídico-administrativas adoptadas -inspección y control- no obtuvieron los resultados esperados ${ }^{77}$ por lo que el Ayuntamiento ha decidido hacer frente a esta situación a través de los esperados instrumentos normativos. Tras suspender el 1 de julio de 2015 el otorgamiento de licencias y autorizaciones municipales ${ }^{78}$ se ha decidido actuar sobre el planeamiento urbanístico con objeto de regular su adecuada implantación en Barcelona, siendo objeto de un intenso debate las zonas en las que se autorizarán estos concretos usos vacacionales -turísticas, residenciales o mixtas-. De modo que Barcelona y Valencia se postulan como las ciudades en España que regularán el alquiler de habitaciones para uso turístico en las viviendas, aunque no serán las pioneras.

En efecto, la Comunidad andaluza se ha desmarcado con un recentísimo decreto de este mismo año, gracias al que, desde mayo de 2016, se permite la cesión turística de viviendas completas pero también de viviendas por habitación. Para ello deben concurrir ciertos requisitos, como son que su propietario o propietaria residan en ella; que no se superen las 6 plazas ${ }^{79}$; que esté ubicada en suelo residencial; disponga de licencia de ocupación o documento equivalente y que se haya presentado declaración responsable e inscrito en el Registro de Turismo, además de los concretos requisitos que establece el art. 6 en cuanto a los servicios comunes de la vivienda ${ }^{80}$.

76 El barrio marítimo de la Barceloneta es uno de los más afectados por el conflicto de convivencia entre ciudadanos y turistas, produciéndose continuas movilizaciones vecinales contra las viviendas turísticas y el turismo en general, propugnando un modelo turístico «menos agresivo para la ciudad y respetuoso con la identidad del barrio». Véase Cuscó PUIGDELLívOL, E., FONT GAROLERA, J., "Nuevas formas de alojamiento turístico: comercialización, localización y regulación de las viviendas de uso turístico en Cataluña”, BibliozW, Revista Bibliográfica de Geografía y Ciencias Sociales, n.ำ1.134, 2015, p. 7.

77 En julio de 2014, de un total de 284 expedientes sancionadores contra propietarias y propietarios por irregularidades en el alquiler de apartamentos turísticos y viviendas de uso turístico, la Dirección General de Turismo de Cataluña resolvió 103, imponiendo sanciones por un total de 537.000 euros. Sólo en Ciutat Vella ya hay 313 viviendas sancionadas en 2015. Por este motivo, han puesto en marcha un plan piloto para "reconvertir" los alquileres ilegales de viviendas turísticas en viviendas sociales, de modo que los propietarios que cedan en alquiler durante 3 años estas viviendas a la Mesa D’ Emergència Social del Consorcio de Vivienda de Barcelona podrán reducir su sanción hasta en un $80 \%$; empezarán a percibir el alquiler una vez hayan satisfecho la sanción. Pero también se han impuesto sanciones a las propias plataformas virtuales en las que se ofertaba el alquiler de viviendas turísticas sin licencia e inscripción en el registro correspondiente, como en el caso de AirBnb por importe de 30.000 euros. Información disponible en la página de la Generalitat de Catalunya (http://www.bcn.cat/consorcihabitatge/es/suport_emergencia_social.html)

78 El anuncio de información pública de 1 de julio de 2015 (BOP Barcelona, 2/07/2016) establece la suspensión de hasta un año de la concesión de licencias y autorizaciones administrativas para la apertura, instalación o ampliación de hoteles de cualquier categoría, hostales, pensiones, residencias para estudiantes, albergues juveniles y establecimientos de apartamentos turísticos, de acuerdo al art. 73.3 del Decreto Legislativo 1/2010, de 3 de agosto, por el que se aprueba el Texto Refundido de la Ley de urbanismo de Cataluña. En la nota de prensa, el Ayuntamiento de Barcelona hace mención a varios problemas derivados de las HUT: por un lado, los derivados de la convivencia vecinal, como son la dificultad para compatibilizar los usos residenciales y los turísticos en barrios históricos, conformados por construcciones antiguas y calles estrechas, que incrementan los problemas de convivencia y facilitan el conflicto. Pero también los derivados del incremento de actividades que suponen un deterioro de las instalaciones y zonas comunes de los edificios residenciales y el aumento de la inseguridad en dichos edificios debido a la constante entrada y salida de los residentes temporales. Por otro lado, los problemas legales derivados del alquiler fraudulento de habitaciones individuales o incluso de camas dentro de una misma habitación, supuesto no contemplado por la normativa catalana.

79 Artículo 5 del Decreto 28/2016, de 2 de febrero, de las viviendas con fines turísticos y de modificación del Decreto 194/2010, de 20 de abril, de establecimientos de apartamentos turísticos, que establece los tipos de viviendas turísticas: "1. Las viviendas con fines turísticos podrán ser: a) Completas, cuando la vivienda se cede en su totalidad. b) Por habitaciones, debiendo la persona propietaria residir en ella. En estos casos, podrán utilizar las denominaciones internacionalmente reconocidas para este tipo de alojamiento. 2. La capacidad máxima de éstas, vendrá limitada a lo dispuesto en la licencia de ocupación. En todo caso, cuando el uso de la vivienda sea completo no podrá ser superior a quince plazas y cuando el uso sea por habitaciones, no podrá superar las seis plazas, no pudiendo exceder en ambos tipos de cuatro plazas por habitación".

80 Artículo 6. Requisitos y servicios comunes. "Las viviendas con fines turísticos deberán cumplir con los siguientes requisitos: a) Disponer de licencia de ocupación, y cumplir en todo momento con las condiciones técnicas y de calidad exigibles a las viviendas. b) Las habitaciones tendrán ventilación directa al exterior o a patios y algún sistema de oscurecimiento de las ventanas. Este requisito no será exigible cuando la vivienda o el edificio en el que se integra esté catalogado como Bien de Interés Cultural y el nivel de protección impida realizar algún tipo de obra, modificación o intervención que sea necesaria para cumplir con el requisito. c) Estar suficientemente amuebladas y dotadas de los aparatos y enseres necesarios para su uso inmediato y acorde al número de plazas de que dispongan. d) Refrigeración por elementos fijos en las habitaciones y salones, cuando el período de funcionamiento comprenda los meses de mayo a septiembre, ambos inclusive. Si el periodo de funcionamiento comprende los meses de octubre a abril, ambos inclusive, deberán contar con calefacción. Este requisito no será exigible cuando la vivienda o el edificio en el que se integra esté catalogado como Bien de Interés Cultural y el nivel de protección impida realizar algún tipo de obra, modificación o intervención que sea necesaria para cumplir con el requisito. e) Botiquín de primeros auxilios. f) Disponer de información turística, en soporte físico o electrónico, de la zona, zonas de ocio, restaurantes y cafeterías, comercios y tiendas de alimentos, los aparcamientos más próximos a la vivienda, servicios médicos existentes en la zona, medios de transporte urbano, plano de la localidad y guía de espectáculos. g) Todas las viviendas dispondrán de Hojas de Quejas y Reclamaciones a disposición de las personas usuarias, y de cartel anunciador de las mismas en un lugar visible dentro de la vivienda. h) Limpieza de la vivien-

REALA, Nueva Época, - N. ${ }^{\circ}$ 5, enero-junio 2016 - ISSN: 1989-8975 - DOI: 10.24965/reala.voi5.10350 
A pesar de este planteamiento autonómico mayoritariamente contrario a permitir el arrendamiento de habitaciones turísticas, la Comisión Nacional de los Mercados y de las Competencia se muestra claramente a favor de que las Comunidades Autónomas permitan estas cesiones de uso. Es cierto que hasta el momento la CNMC había adoptado un papel activo en la defensa de la economía colaborativa, demostrando que su postura era favorable a su existencia ${ }^{81}$ y a su no regulación. En este sentido sostiene que, tras realizar una labor de seguimiento y revisión del conjunto de la normativa existente al efecto, en aras de la promoción de la competencia y la una regulación económica suficiente, no debería someterse a regulación ya que, de forma general, perjudicaría a los consumidores y al interés general, además de suponer un obstáculo a la competencia efectiva. Así ha quedado claro tras la interposición de sendos recursos contra los Decretos de Madrid -ya resuelto- ${ }^{82}$ y Aragón. En concreto, en cuanto a la prohibición de cesión del uso de la vivienda por estancias con fines turísticos ${ }^{83}$, sostiene que constituye una limitación tanto del número de operadores que podrían ofertar sus servicios en el mercado como de las posibilidades de elección de los consumidores finales, además de suponer una restricción a la capacidad para competir de los operadores ya instalados y los nuevos.

\section{LA INEXISTENCIA DE UN MARCO NORMATIVO ADECUADO QUE OTORGUE GARANTÍAS AL USUARIO TURÍSTICO}

El segundo de los motivos que ha puesto en pie de guerra a los colectivos hoteleros e incluso a la propia Administración es la inexistencia de una regulación específica que establezca las garantías necesarias que protejan al usuario de este tipo de alojamiento turístico, lo que puede derivar no sólo en una merma de la calidad de la oferta turística de nuestro país ${ }^{84}$, sino también en que los propios ofertantes del alojamiento puedan incurrir en diversas infracciones administrativas y tributarias, como de hecho ha ocurrido en no pocos casos confrontados con las correspondientes normativas de diferentes Comunidades Autónomas. Y es que la calidad de esta oferta se ha convertido en un principio general esencial que recorre toda la materia turística. El turista se guía por la comodidad y la calidad del servicio, siendo ésta predicable de cualquier actividad y extendiéndose, por tanto, a la calidad de los bienes más variados - desde la conservación del patrimonio histórico a la protección del entorno urbano o del medio natural- y de todos los productos turísticos imaginables, así como a la excelencia de los operadores turísticos del sector privado y de las propias Administraciones Públicas.

Y cuando el énfasis se pone en la calidad, la clave para alcanzar estos objetivos pasa por la ordenación administrativa de los operadores turísticos, así como de los bienes y productos turísticos, por lo que el Dere-

da a la entrada y salida de nuevos clientes. i) Ropa de cama, lencería, menaje de casa en general, en función a la ocupación de la vivienda y un juego de reposición. j) Facilitar a las personas usuarias un número de teléfono para atender y resolver de forma inmediata, cualquier consulta o incidencia relativa a la vivienda. k) Tener a disposición de las personas usuarias información e instrucciones de funcionamiento de electrodomésticos u otros dispositivos que lo requieran para su correcto uso. l) Informar a las personas usuarias de las normas internas relativas al uso de las instalaciones, dependencias y equipos de la vivienda, así como la admisión y existencia de mascotas en la vivienda, restricciones para personas fumadoras así como las zonas de uso restringidos".

81 En este sentido, afirma que la oferta de alquiler de viviendas de uso turístico conlleva, con carácter general, importantes beneficios desde el punto de vista de la promoción de la competencia y la regulación económica eficiente, ya que supone una mayor oferta para el consumidor; constituye una asignación más eficiente de los recursos infrautilizados; genera externalidades positivas; reduce costes de transacción y problemas de información, produciendo, en definitiva, efectos para la competencia entre los operadores tradicionales. Véase el Informe de la Comisión Nacional de los Mercados y de la Competencia, IPN/CNMC/007/15, sobre el Proyecto de Decreto del Gobierno de Aragón por el que se aprueba el Reglamento de las viviendas de uso turístico en Aragón, de 16 de abril de 2015.

82 En efecto, la CNMC impugnó el Decreto 79/2014, de 10 de julio, de la Comunidad de Madrid por el que se regulan los apartamentos turísticos y las viviendas de uso turístico, por establecer un período mínimo de pernoctas ( 5 días), lo que supone, a su juicio, un obstáculo a la competencia efectiva en este mercados al restringir la capacidad de elección del consumidor, eliminando del mercado a cierto tipo de operadores, lo repercutirá en el precio que los consumidores deban pagar por el alojamiento. El pasado 31 de julio se dictaron sendas sentencias por el TSJ de Madrid que declararon la nulidad de este inciso. Véase a este respecto la Nota al pie n. 70.

La impugnación contra el Decreto de Canarias, Decreto 113/2015, de 22 de mayo, por el que se aprueba el Reglamento de viviendas vacacionales, se fundamentó en los numerosos obstáculos encontrados en el mismo al desarrollo de una competencia efectiva en el mercado del alojamiento turístico, que elevaban injustificadamente los costes de entrada en el mercado, desalentando a algunos operadores que ya estaban participando en el mismo con nuevos modelos de prestación de servicio y a otros potenciales oferentes, reduciendo así el número de competidores y los incentivos a que se den precios más eficientes y competitivos para los usuarios. En concreto, es objeto de impugnación, entre otros motivos, el hecho de que no se permita el alquiler por estancias, ni tampoco se permita el de las viviendas que estén situadas en suelos, zonas y urbanizaciones turísticas. Véase la Nota de prensa de 18 de septiembre de 2015 en la página web de la CNMC (https://www. cnmc.es/CNMC/Prensa/Tabld/254/ArtMID/6629/ArticleID/1433/La-CNMC-requiere-al-Gobierno-de-Canarias-que-suprima-o-modifique-distintosart237culos-de-su-reglamento-de-viviendas-vacacionales.aspx).

83 Informe de la Comisión Nacional de los Mercados y de la Competencia, IPN/CNMC/007/15, sobre el Proyecto de Decreto del Gobierno de Aragón por el que se aprueba el Reglamento de las viviendas de uso turístico en Aragón, de 16 de abril de 2015.

84 No existe un concepto de este término en el campo turístico; ahora bien, la calidad constituye, ciertamente, un objetivo de la prestación de cualquier servicio turístico, de su realización efectiva, y por consiguiente actúa de principio rector de las técnicas empresariales, de los modos gerenciales, en definitiva, de la propia realidad técnica en la que consista cada actividad. Véase BERMEJo VERA, J., Derecho Administrativo. Parte especial, op. cit., p. 1013. 
cho se erige en herramienta indispensable en el estudio y análisis del sector turístico ${ }^{85}$. Velar por mantener el adecuado equilibrio entre todas las partes es tarea del Derecho Administrativo ya que, como sabemos, las normas turísticas persiguen fines frecuentemente antagónicos que tratan de proteger al turista y a la vez proteger a la industria turística ${ }^{86}$. El ordenamiento sectorial del turismo no camina ya por la senda de la autonomía de la voluntad, sino de la ordenación pública de las relaciones inter privatos ${ }^{87}$, teniendo los poderes públicos una activa participación orientada a la protección y tutela de los consumidores y usuarios ${ }^{88}$, que desplaza la autonomía de la voluntad de las partes, ya que no son enteramente libres para fijar a su arbitrio y antojo el contenido obligacional del vínculo contractual. Es importante destacar el doble nivel de protección que nuestro ordenamiento jurídico dispensa al turista, en cuanto consumidor por un lado, y en cuanto usuario turístico por otro ${ }^{89}$.

Por todo ello, la ordenación de esta nueva figura resulta muy necesaria, pese a que el sentir general, conforme a los dictados las denominadas free culture ${ }^{90}$, entienda que lo colaborativo resulta positivo y por tanto no deba ser regulado. La regulación del sector turístico está más que justificada, si tenemos en cuenta las consecuencias que se pueden derivar de una ordenación inadecuada del mismo, tanto en materia de protección de los usuarios, del territorio y medio ambiente o la protección del patrimonio cultural ${ }^{91}$. Veamos el porqué de la necesidad de regular esta nueva actividad desde estos puntos de vista.

\subsection{Protección de los usuarios turísticos}

A nuestro modo de ver, los usuarios de este tipo de alojamiento no reglado se encuentran en una clara situación de desamparo legal frente a los que utilizan los modelos habituales de hospedaje. La razón es simple: no existe normativa que establezca unos estándares mínimos de calidad, salubridad o seguridad que deban ser cumplidos por quienes ofrecen este nuevo tipo de estancia turística. Así, a nivel administrativo, no se exigen garantías de higiene y salubridad en las viviendas que son cedidas a través de estas plataformas, por lo que los usuarios quedan desprotegidos como consumidores al no establecerse la obligatoriedad de servicios generales de limpieza, ni la exigencia de unos controles sobre la higiene ${ }^{92}$, el nivel de ruidos u olores en los inmuebles. Su inobservancia queda, por tanto, al margen del régimen sancionador previsto para este tipo de incumplimiento por los alojamientos hoteleros.

Por otro lado, los inmuebles cuyas habitaciones se ceden para uso turístico carecen de la seguridad estructural y de las medidas de protección de las que disfruta el turista en cualquier establecimiento de alojamiento turístico, tales como insonorización, sistemas de extinción de incendios, señales de evacuación, luminosidad, ven-

85 PeÑARRUBiA IZA, J., Moralo IZA, V.M., "Promoción y ordenación del turismo de congresos. Reflexiones en torno al OPC", en MELGoSA ARCOS, F.J. (Coord.), Derecho y Turismo, Salamanca, Ediciones Universidad de Salamanca, 2004, pp. $271-288$, p. 272.

86 Villar PalAsí, J.L., Prólogo en Fernández Álvarez, J., Curso de Derecho Administrativo Turístico I, Editora Nacional, Madrid, 1970.

87 BlAnquer CRIADO, D., Derecho del Turismo, Valencia, Tirant lo Blanch, 1999, p. 50. En el mismo sentido, Bádenas sostiene la creciente importancia de la incidencia de las normas de Derecho Público sobre las relaciones privadas; un mayor control sobre la actividad de los agentes económicos por medio de disposiciones administrativas, indirectamente consolida situaciones que favorecen a los particulares. Véase BÁDENAS CARPIO, J.M., “El contrato de hospedaje”, en PETIT LAVALL (Coord.), M.T., Lecciones de Derecho del Turismo, Valencia, Tirant lo Blanch, 2000, p. 298.

88 Las características de la ordenación jurídica del turismo no han sido delimitadas ni en su desarrollo ni en sus efectos en relación con la legislación genérica de defensa del consumidor, ya que esta última ha sido calificada por el Tribunal Constitucional (STC 86/1982, de 30 de noviembre) como una legislación de «contornos imprecisos», caracterizada por su heterogeneidad y que informa a los distintos sectores en los que se introducen medidas protectoras, incluido el turismo. Véase FERNÁNDEZ RoDRíGUEZ, C., Derecho Administrativo Turístico, Madrid, Marcial Pons, 2013, p. 19.

Como hemos visto, también el turista es, a estos efectos, un consumidor. En algunos aspectos la normativa turística es parte integrante de la del consumo, razón por la que se considera informada por el principio de defensa del consumidor en virtud de la obligación que se impone al legislador en el art. 51 CE. De este modo, la ordenación turística no puede ser ajena a la genérica de defensa del consumidor, sino que más bien ha de entenderse integrada, por un lado, en la normativa del consumo de forma complementaria, subsidiaria y genérica, y por otro, con normas sectoriales específicas, tales como las alimenticias, sanitarias, de higiene, seguridad o medio ambiente (GARCíA SAURA, P.J., Desarrollo sostenible y turismo. Análisis del régimen jurídico medio ambiental de la legislación turística española, Madrid, Thomson-Aranzadi, 2007, p. 89).

89 GUILLÉn CARAmÉs, J., "Algunos aspectos de la protección jurídica del turista”, Revista Española de Derecho Administrativo, n. 115 , 2002, p. 379.

90 La generalización de esta free-culture constituye un cambio en la sociedad que persigue la construcción social del valor que supone entrar a formar parte de una amplia red donde es posible compartir valores comunes y construir proyectos de autonomía. Las cadenas de distribución, tradicionalmente en manos de empresas, han pasado a integrar canales de distribución sustentadas por la actividad de los individuos; ya no tienen que depender de las organizaciones y pueden estar soportadas por redes de individuos, que toman el control. Véase CARDOSO, G., JACOBETTY, P., "Navegando por la crisis: culturas de pertenencia y cambio social en red”, en CARDOso, G. (Ed.), Sociología de las pantallas, Editorial UOC, 2014, p. 170.

91 BouAzZA ARIÑO, O., "El turismo”, en CANO CAMPOS, T., Lecciones y materiales para el estudio del Derecho Administrativo. Tomo VIII, Los sectores regulados, vol. II, Madrid, lustel, 2009, pp. 153-182, p. 153.

92 Sobre esta materia véase PÉREZ GUERRA, R., "La intervención administrativa en el sector turístico español. La política turística”, Revista Aragonesa de Administración Pública, n. ${ }^{\circ}$ 43-44, 2014, pp. 396-413. 
tilación, o incluso eficiencia energética. Medidas todas ellas que también fijan umbrales mínimos de calidad del servicio de alojamiento.

Tampoco se da ningún control en cuanto a la seguridad se refiere. La Ley Orgánica 4/2015, de 30 de marzo, de protección de la seguridad ciudadana, contempla las actividades de hospedaje como relevantes para la seguridad ciudadana y establece la obligación de registro documental e información de los viajeros que utilicen los establecimientos de hospedaje (art. 25) ${ }^{93}$. Sin embargo, bajo esta modalidad de turismo no reglado no hay registro de datos de los clientes que deban ser puestos a disposición de las Fuerzas y Cuerpos de Seguridad del Estado, lo que pone en duda la seguridad desde el punto de vista de los registros policiales, quedando los usuarios de estas viviendas turísticas sustraídos a este control.

Otra cuestión a la que necesariamente debemos hacer referencia es la de la responsabilidad por las posibles incidencias que perjudiquen al pernoctante o al anfitrión -propietario de la vivienda-. Tomando como ejemplo el caso de la precursora del alojamiento vacacional residencial, la plataforma AirBnb, el hecho de que opere online en todo el mundo realizando tareas de intermediación entre particulares implica una actividad no regulada por prácticamente ningún ordenamiento jurídico. Este limbo jurídico ha sido aprovechado por esta empresa para eximirse de toda responsabilidad en su actuación, como bien recoge en las Condiciones de Servicio que tiene publicadas en su página web ${ }^{94}$. De su lectura extraemos que esta plataforma establece que no es arrendataria, propietaria, intermediaria, gestora, ni tiene relación alguna con ninguna de las dos partes, por lo que se declara no responsable en modo alguno de lo que pudiera acaecer durante la estancia vacacional ${ }^{95}$. En este caso, el hecho de que este sistema se sustente sobre la confianza y la reputación de los usuarios no supone, en realidad, garantía de ningún tipo desde el momento en que es posible cerrar un perfil y abrir uno nuevo con una identidad distinta, haciendo tabula rasa.

\subsection{Protección del medio ambiente y del territorio}

Asimismo, la protección del medio ambiente y del entorno urbano constituye otra de las razones que justifica la necesidad de regulación de estas cesiones de uso turístico. No se puede obviar la importancia y el impacto que este tipo de actividad y, sobre todo, este tipo de alojamiento produce sobre el territorio y la repercusión directa sobre la comunidad donde se integra. Esta nueva oferta turística puede alterar las relaciones con el resto de resi-

93 Art. 25: 1. Las personas físicas o jurídicas que ejerzan actividades relevantes para la seguridad ciudadana, como las de hospedaje, transporte de personas, acceso comercial a servicios telefónicos o telemáticos de uso público mediante establecimientos abiertos al público, comercio o reparación de objetos usados, alquiler o desguace de vehículos de motor, compraventa de joyas y metales, ya sean preciosos o no, objetos u obras de arte, cerrajería de seguridad, centros gestores de residuos metálicos, establecimientos de comercio al por mayor de chatarra o productos de desecho, o de venta de productos químicos peligrosos a particulares, quedarán sujetas a las obligaciones de registro documental e información en los términos que establezcan las disposiciones aplicables. Constituye, por tanto, una obligación de los titulares de estos establecimientos hoteleros cumplimentar el libro-registro y presentar los partes de entrada de viajeros, de acuerdo con lo establecido en la Orden INT/1922/2003, de 3 de julio, sobre libros-registro y partes de entrada de viajeros en establecimientos de hostelería y otros análogos.

94 Así, en las “condiciones del servicio" establece que la página, la aplicación y los servicios componen una plataforma por internet a través de la cual los anfitriones pueden crear listados para alojamientos y los clientes pueden obtener información sobre alojamientos y reservarlos directamente con los anfitriones. usted acepta y conviene que AirBnb no es parte de ningún acuerdo firmado entre los anfitriones y los clientes, ni tampoco es una agencia inmobiliaria, agente o aseguradora. AirBnb no tiene ningún control sobre la conducta de anfitriones, clientes y otros usuarios de la página, la aplicación o los servicios o de ningún alojamiento, y rechaza toda responsabilidad a este respecto en la medida máxima de lo permitido por ley. En cuanto al funcionamiento de la página web, aplicación y servicios señala que salvo por lo expresamente especificado en contrario en la plataforma de AirBnb, las responsabilidades de AirBnb están limitadas a: (i) facilitar la disponibilidad de la Página web, la Aplicación y los Servicios, y (ii) actuar como agente de cobros limitado de cada Anfitrión al objeto de aceptar, en su nombre y representación, los pagos de los Clientes. En cuanto al listado de alojamientos sostiene tenga presente que AirBnb no asume ninguna responsabilidad en relación al cumplimiento por parte del Cliente de los acuerdos u obligaciones asumidos frente a otros terceros, las leyes, normas y reglamentos aplicables.

Y por si quedaban dudas, añade, en el apartado de "responsabilidad" una exención completa de responsabilidad, haciendo que sean los usuarios de la página web quienes asuman todo el riesgo, junto con una cláusula de "no respaldo": Al utilizar la Página web, la Aplicación o los Servicios, usted acepta que cualquier recurso o responsabilidad legal que pretenda obtener a causa de acciones u omisiones de otros Miembros o terceros estará limitado a una reclamación contra los Miembros o terceros particulares causantes de los daños. Usted conviene que no intentará imponer responsabilidad sobre AirBnb, o buscar ningún remedio legal por parte de AirBnb con respecto a dichas acciones u omisiones. Pueden consultarse estas condiciones en la página web de AirBnb, disponible online en https://www.AirBnb.es/terms (consulta en el mes de mayo de 2016).

95 De ahí que, en sus inicios, AirBnb careciera de seguro alguno que cubriera las posibles incidencias derivadas del uso de terceros que contrataban a través de su página. Pero desde finales de 2011 ha añadido esta cobertura a los anfitriones a raíz de un incidente en San Francisco, donde un turista que había reservado una estancia a través de su página saqueó la vivienda. Desde esa fecha, AirBnb cuenta con un seguro que cubre las estancias y, además, con un centro de seguridad y confianza. Solicita, asimismo, el pasaporte escaneado cuando alguien se registra, pero esta información no es accesible para el resto de los registrados, ni siquiera para quienes sean anfitriones, lo que también genera el consiguiente problema de tratamiento de datos personales, de conformidad con lo que establece la Ley Orgánica 15/1999, de 13 de diciembre, de Protección de Datos de Carácter Personal.

REALA, Nueva Época, - N. ${ }^{\circ}$ 5, enero-junio 2016 - ISSN: 1989-8975 - DOI: 10.24965/reala.voi5.10350 
dentes del edificio en el que radica esta vivienda turística, con una potencial incidencia negativa en la normal convivencia de la comunidad y un deterioro en su calidad de vida ${ }^{96}$. La mezcla de usos ${ }^{97}$ genera numerosos problemas ya que los residentes tienen unos hábitos, aspiraciones y horarios bastante diferentes de los turistas allí ubicados, que residen sólo durante unos días, buscan diversión y entretenimiento y, por lo general, provocan un nivel de ruido mucho mayor que el de aquellos ${ }^{98}$. Asimismo, el incremento de la actividad en ciertos inmuebles puede suponer un mayor o más rápido deterioro de instalaciones y zonas comunes de dichos edificios residenciales, junto al aumento de la inseguridad que pudiera provocar la constante entrada y salida de los residentes temporales.

La convivencia vecinal es la causante de que los Ayuntamientos de numerosas ciudades hayan optado por no otorgar licencias para viviendas turísticas, como ha ocurrido en Barcelona o en Valencia, donde la Administración ha optado por la anulación de las licencias concedidas para la actividad profesional de empresa gestora de cesión a título oneroso de uso y disfrute de viviendas de uso turístico, justificando su actuación en la inexistencia de comunicación ambiental oportuna, de acuerdo a lo establecido en la Ley 6/2014, de 25 de julio, de prevención, calidad y control ambiental de actividades en la Comunidad Valenciana99. Esta Ley, dictada en el marco del mandato general de protección del medio ambiente, ex art. 45 CE, configura la licencia ambiental como instrumento autorizatorio de carácter municipal al que se sujetan ciertas actividades productivas que tienen una elevada incidencia potencial sobre el medio ambiente. En este anexo se recogen las categorías de actividades sujetas a licencia ambiental y en el apartado $13.2 .7 .^{\circ}$ se establece que, por implicar cierto grado de riesgo, estarán sometidas a licencia ambiental los hoteles, establecimientos de alojamiento turístico rural, bloques y conjuntos de apartamentos turísticos, campamentos de turismo, establecimientos de restauración y establecimientos de turismo, cuya altura de evacuación sea superior a 28 metros o la superficie total construida sea mayor de $1.500 \mathrm{~m} 2$, salvo que se incluyan en normativa específica. Dado que se trata de oferta turística reglada, esta licencia ambiental no parece que pudiera ser exigible a las viviendas turísticas ya que no se recogen

96 La jurisprudencia destaca como actividades contrarias a la convivencia normal de la comunidad «aquellas que causan a los vecinos de la finca molestias de tal entidad que no vienen obligados a soportar al superar las normales que derivan de una relación de vecindad», siendo los criterios orientativos que sirven para fijar los límites de estas actividades molestas tanto la naturaleza del inmueble, sobre todo cuando se trata de edificios destinados mayoritariamente a vivienda habitual, como las condiciones del lugar, como que el edificio se encuentre en una zona residencial de ciudad y el uso que se haga del inmueble por parte de quien explota turísticamente la vivienda (pudiendo ser adecuado y de buena fe o excesivo e inadecuado (FUENTES-LOJO RIUS, A., "Prohibición de explotación turística de la vivienda por ser contraria a la convivencia normal de la comunidad de propietarios”, Diario La Ley, n. ${ }^{8}$ 709, 2016, p. 1). Se trata, en definitiva, de un criterio jurisprudencial seguido desde los años setenta -Sentencia de la Audiencia Provincial de Granada de 19 de abril de 1975 y de 7 de febrero de 1976; y Sentencia de la Audiencia Provincial de Oviedo de 12 de abril de 1976-, que tiene como claro exponente la STS de 23 de noviembre de 1995, que considera que estas actividades «sobrepasan los límites normales de la tolerancia a que obligan las normas de convivencia social». Así, la Sentencia de la Audiencia Provincial de La Coruña de 16 de mayo de 1996 señala que la industria del hospedaje conlleva unas molestias potenciales que exceden de las que la convivencia en un régimen de propiedad horizontal obliga a soportar. Más recientemente, la Sentencia de la Audiencia Provincial de Barcelona, n. ${ }^{\circ}$ 384/2011, de 12 de julio se ha pronunciado en el mismo sentido (GuILLÉn NAVARRO, N.A., "La vivienda de uso turístico y su incidencia en el panorama normativo español”, Revista Aragonesa de Administración Pública, n. ${ }^{\circ}$ 45-46, 2015, p. 134). También la Sentencia de la Audiencia Provincial de Barcelona de 13 de febrero de 2015 ha resuelto que la explotación turística de tres apartamentos de un edificio dividido en propiedad horizontal es contraria a la convivencia normal de la comunidad en base a que la explotación turística se realiza en un edificio residencial plurifamiliar y se ha acreditado que se ha realizado un uso indebido del edificio que provoca molestias, como el trasiego constante de personas y cosas durante el día y la noche, que provoca ruidos a los vecinos y genera suciedad en la escalera y patio comunitarios, así como llamadas esporádicas y equivocadas a interfonos de vecinos, etc.

Por el contrario, el criterio jurisprudencial valenciano entiende que la cesión de uso turístico de las viviendas no afecta o no tiene por qué afectar al medio ambiente en mayor medida que un arrendamiento de vivienda de la LAU. Así se establece en la Sentencia del Juzgado de lo Contencioso-Administrativo n. ${ }^{\circ} 6$ de Valencia (PO 284/2015).

97 No podemos olvidar que resulta problemático el hecho de que estas viviendas se emplacen en zonas residenciales cuando, en realidad, esta actividad de viviendas vacacionales es una modalidad de explotación turística extra-hotelera. En este sentido, la jurisprudencia más reciente se pronuncia acerca de la incidencia de la implantación de un uso distinto del residencial en la vivienda, en concreto un uso terciario, sobre todo a raíz de la problemática surgida en torno a la ordenación por parte del Ayuntamiento de Madrid en cuanto a la suspensión y cese de la actividad de una vivienda vacacional por ejercerse la misma sin la preceptiva licencia municipal (Sentencia del TSJ Madrid de 17 de abril de 2013). Además, se plantea si debe considerarse que se trata de un cambio de uso residencial a terciario, por lo que necesitarían una autorización urbanística que amparase dicha modificación con respecto a lo establecido en el Plan General de Ordenación Urbana del municipio (Sentencias del TSJ Madrid de 24 de febrero de 2011 y de 25 de octubre de 2012). Véase GUILLÉN NAVARRO, N.A., "La vivienda de uso turístico y su incidencia en el panorama normativo español”, op. cit., p. 137. Esta modificación no resulta sencilla; así, por ejemplo, en Cataluña se establece que el destino de una vivienda al uso turístico no es posible si está prohibido por la ordenación de usos del sector donde se encuentre (art. 68.6, Decreto 159/2012, de 20 de noviembre). Mientras que en Aragón se exige declaración responsable acerca de la compatibilidad del uso con el planeamiento urbanístico del municipio (art. 14.1.e, Decreto 80/2015, de 5 de mayo). Véase GUILLÉN NAVARRO, N.A., IÑIGUEZ BERROZPE, T., "Las viviendas de uso turístico en el nuevo entorno p2p. Retos socio-jurídicos para el consumo colaborativo en el alojamiento turístico”, Estudios Turísticos, n. ${ }^{\circ} 205,2015$, p. 28.

98 BlAsco EsteVe, A., "Planificación y gestión del territorio turístico de las Islas Baleares", en MelGosA ARCos, F.J. (Ed.), Derecho y turismo, op. cit., p. 414 .

99 Sobre este particular, véase CORTINA VALLACANERA, J., "Sistema actual de los instrumentos de intervención ambiental en la Comunidad Valenciana”, Práctica urbanística, n.117, 2010, pp. 12-29. Y también MERINO MoLINS, V., "Los instrumentos de intervención ambiental en la Ley 6/2014, de 25 de julio, de Prevención, Calidad y Control Ambiental de Actividades de la Comunidad Valenciana (II). La licencia ambiental y otros medios de intervención", Consultor de los ayuntamientos y los juzgados, n. ${ }^{\circ}$ 7, 2015, pp. 830-838. 
de forma expresa a lo largo de la norma. Sin embargo, el Ayuntamiento de Valencia ha establecido que esta actividad no reglada también debe encuadrarse en el artículo 71 de la Ley 6/2014, que si bien no requiere la preceptiva licencia para el comienzo de esta actividad, sí que la sujeta al régimen de comunicación ambiental previa de actividades inocuas ${ }^{100}$, que debe presentarse junto con la declaración responsable de forma anterior al inicio de la misma. Y todo ello a pesar de que la cesión de uso de una vivienda turística difícilmente puede calificarse como actividad ${ }^{101}$, según el propio concepto que la ley valenciana le otorga.

El impacto que genera esta nueva oferta turística no es, por tanto, a coste cero. En este sentido, estas plataformas virtuales han dado al traste con la planificación turística llevada a cabo por la Administración Pública ${ }^{102}$ como requisito indispensable para asegurar la posibilidad de un desarrollo a largo plazo con beneficios para la comunidad receptora, acercando esta nueva forma de turismo al concepto de turismo no sostenible. Aunque el turismo constituye una incuestionable fuente de riqueza para un gran número de lugares geográficos también conlleva numerosos efectos nocivos sobre el entorno en sentido amplio, afectando a los aspectos económicos, sociales, culturales y medioambientales ${ }^{103}$. Efectos que pueden ser corregidos y evitados gracias a una adecuada planificación llevada a cabo por los responsables de las áreas turísticas.

\subsection{Protección de la economía}

Tampoco podemos olvidar que la inexistencia de normativa al respecto fomenta la economía sumergida, dado que gran parte de los ingresos derivados del arrendamiento de estas estancias no son declarados por las propietarias y propietarios de las viviendas. Según un estudio llevado a cabo por Exceltur ${ }^{104}$ en 2014, si ningún propietario declarase estos ingresos, con un tipo medio del 21\%, el potencial fraude fiscal podría ascender a los 432 millones de euros por año. Asimismo, a pesar de que la normativa sobre el impuesto del IVA no sería de aplicación al alquiler esporádico de la vivienda, el hecho de que se haga con frecuencia convierte a este particular en profesional de la actividad, por lo que se le debería considerar autónomo y estaría obligado a darse de alta en el censo y tributar como tal, pagando el IVA correspondiente de dicha actividad, además de su alta en la Seguridad Social ${ }^{105}$.

100 También el art. 42 de la Ordenanza reguladora de obras de edificación y actividades del Ayuntamiento de Valencia, de 29 de junio de 2012, establece que las actividades que no sean susceptibles de afectar a la seguridad ni producir efectos negativos sobre la salud o el medio ambiente, no sometidas por tanto a autorización ambiental integrada, licencia ambiental o declaración responsable, se tramitarán mediante la presentación ante el Ayuntamiento de una comunicación ambiental previa al inicio de la actividad. La comunicación deberá acompañarse de la siguiente documentación: a) Memoria técnica, suscrita por técnico competente, en la que se describa el local, sus instalaciones y la actividad a desarrollar. b) Certificado de técnico competente en el que se manifieste expresamente la compatibilidad urbanística para la implantación de la actividad, de acuerdo con la normativa urbanística específica aplicable al emplazamiento donde se pretende instalar. c) Certificado de técnico competente en el que conste que la actividad se ajusta a la normativa vigente que le sea de aplicación. d) Aquellas autorizaciones o documentación que vengan exigidas por la normativa sectorial aplicable.

101 Esto es lo que recoge una recentísima sentencia dictada por el Juzgado de lo Contencioso-Administrativo n. ${ }^{\circ} 6$ de Valencia (PO 284/2015), estableciendo que no se entiende en qué medida la cesión de uso remunerada y de forma habitual de viviendas pueda afectar al medio ambiente en mayor medida que un contrato civil de arrendamiento de vivienda sujeta a la LAU.

102 La ordenación de la actividad turística es necesaria y una manera de intervenir es a través de la técnica de la planificación, como herramienta de protección territorial y crecimiento global equilibrado mediante una ordenación racional; para que el turismo sea sostenible necesita estar integrado en la planificación general del territorio para conseguir en equilibrio entre desarrollo económico y respeto de los valores ecológicos, culturales y sociales (BOUAZZA ARIÑO, O., “El turismo", en CANO CAMPOS, T., Lecciones y materiales para el estudio del Derecho Administrativo. Tomo VIII, Los sectores regulados, op. cit., p. 174). Planificar significa, sobre todo, poner racionalidad en el futuro, que ayude a dar una dirección positiva y oportuna a los legítimos intereses de los ciudadanos de promoción y desarrollo (CANTOS MARTíN, R., "La planificación turística y los entes públicos de gestión en el desarrollo de las grandes ciudades: los modelos de Barcelona y Londres”, Ciudad y Territorio. Estudios Territoriales, n. ${ }^{182}$, 2014, pp. 649-670). Hasta el pasado año, fue el Plan Nacional e Integral de Turismo, para el período 2012-2105, a través de la Secretaría de Estado de Turismo. Uno de los objetivos establecidos era el de mejora de la oferta, en términos de rentabilidad empresarial y percepción por parte del turista.

103 En la aplicación del modelo de turismo sostenible se utiliza frecuentemente el concepto de "capacidad de carga”, que implica que los lugares turísticos poseen ciertos límites en el volumen y la intensidad que puede soportar una zona geográfica determinad, sin que provoque daños determinados (LóPEZ BONILLA, J.M, LóPEZ BONILLA, L.M., "La capacidad de carga turística: revisión crítica de un instrumento de medida de sostenibilidad", El periplo sustentable, n. ${ }^{\circ} 15,2008$, p. 125). Si esto es así, debemos añadir, la capacidad de carga de una zona residencial debe ser muy inferior a las que ostentan las zonas turísticas, lo que las convierte en reductos sumamente frágiles ante dichas intensidades de uso, por lo que se hace necesario racionalizar el uso abusivo y el deterioro de los recursos que suponen las actividades turísticas. En cuanto al turismo, la calificación del uso del suelo y los estándares urbanísticos, véase BLANQUER CRIADo, D., Derecho del Turismo, op. cit, pp. 146 y ss.

104 Informe sobre alojamiento turístico en viviendas de alquiler: impactos y retos asociados (impactos sociales y económicos sobre los destinos españoles derivados del exponencial aumento del alquiler de viviendas turísticas de corta duración, impulsado por los nuevos modelos y canales de comercialización p2p), junio de 2015, Exceltur, EY y Tourism Law. Disponible online en http://www.exceltur.org/wp-content/ uploads/2015/06/Alojamiento-tur\%C3\%ADstico-en-viviendas-de-alquiler-Impactos-y-retos-asociados.-Informe-completo.-Exceltur.pdf.

105 El elemento que sirve de puente entre la tributación y la no tributación de IVA es la constatación de prestación de servicios propios de la industria hotelera. Así, en principio, los arrendamientos de apartamentos por personas físicas se consideran exentos de IVA siempre y cuando el arrendador no se obligue a prestar alguno de los servicios propios de la industria hotelera, tales como limpieza del interior del apartamento prestado con periodicidad semanal y cambio de ropa con la misma periodicidad; no se consideran servicios propios de la industria hotelera los relativos a la limpieza del interior del apartamento a la entrada y a la salida del período contratado por cada arrendatario; cambio 
Y ello contando con que quien realiza la operación sea, en realidad, un particular, puesto que el fraude se incrementa cuando se trata de grandes empresas que, publicitándose como particulares, obtienen pingües beneficios prácticamente a coste cero.

En el mismo sentido, y en cuanto a la normativa fiscal se refiere, también estas plataformas parecen eludir las obligaciones fiscales o administrativas relacionadas con la actividad que realizan, como se ha puesto de manifiesto en Barcelona. Sin embargo, no creemos que el problema sea tanto de estas plataformas como del hecho de que no exista una normativa ad hoc que establezca sus concretas obligaciones de pago; en el caso de AirBnb, cuando sus obligaciones fiscales han sido perfiladas por el ordenamiento jurídico, ha acabado por satisfacerlas, como ha ocurrido en Estados Unidos.

Por otro lado, este nuevo mercado turístico creado por estas plataformas virtuales ha colocado en una clara situación de desventaja competitiva a los alojamientos reglados. No es factible competir contra quien no sigue las reglas del juego o quien dice jugar en una liga distinta. Así las cosas, quienes ofertan alojamiento reglado deben hacer frente a unos costes que, sin embargo, quienes ofrecen habitaciones en su vivienda a cambio de una contraprestación no deben sufragar, lo que facilita que estos últimos puedan ofrecer alojamiento a los turistas a precios significativamente inferiores. Los estándares mínimos de calidad y seguridad que ofrecen los establecimientos reglados tienen un coste que repercutirá en el consumidor final, lo que hace que esta oferta sea económicamente menos atractiva de cara al mercado turístico.

Por todo ello resulta evidente que la regulación es necesaria. Y lo es a pesar de lo que sostiene la CNM en su informe ${ }^{106}$, al decir que una regulación innecesaria o desproporcionada perjudicaría a los consumidores. Nada más lejos de la realidad a nuestro parecer; el Derecho debe establecer pautas de funcionamiento cuando lo que está en juego es, entre otras cosas, la seguridad de los turistas que ocupan las viviendas. No abogamos por la supresión de esta nueva forma de turismo, ni mucho menos, pero resulta necesario que se aborde su regulación jurídica dado que la carencia de unos estándares mínimos que sí se exigen a los alojamientos reglados y la inexistencia de control no favorece en modo alguno el modelo de turismo sostenible y de calidad que se intenta crear en España. Debe buscarse, por ello, el equilibrio justo entre el disfrute turístico y la tranquilidad de los vecinos, lo que podría lograrse estableciendo una regulación coherente y la exigencia de ciertos condicionantes que atiendan al logro de la calidad y la sostenibilidad de este nuevo tipo de turismo.

\section{EL ALOJAMIENTO COLABORATIVO ¿ES REALMENTE COLABORATIVO?}

Como hemos visto, la nueva filosofía de vida que rodea al fenómeno del colaboracionismo gira en torno a dos ideas clave. La primera de ellas es el reaprovechamiento, de bienes, servicios y tiempo; dar una segunda oportunidad a aquello que ya no utilizamos y cuya vida útil puede ser prolongada por terceros; reaprovechar para que el hiperconsumo que rodea nuestra sociedad sea más sostenible. La segunda idea sobre la que pivota esta alternativa de vida es la visibilización a través de las tecnologías de la información. Las cifras hablan por sí solas y los partidarios de esta nueva filosofía de vida no hacen más que aumentar; en 2014, tres de cada cuatro europeos ya había participado, o creía que lo haría, en servicios de consumo colaborativo; en España, un $75 \%$ de la población ya ha utilizado estos servicios, alquilando o compartiendo algún bien o servicio colaborativo ${ }^{107}$, aunque la realidad es que menos del $20 \%$ tiene claro que se trate de economía colaborativa. Por ello, si es posible sacar mayor rentabilidad de prácticamente todo lo que nos rodea ¿por qué no hacerlo con nuestra vivienda a golpe de click? Las asociaciones pro-alquiler vacacional lo tienen claro: si la economía colaborativa funciona y logra que tengamos un dinerillo extra en época de crisis ¿por qué no aprovecharlo? Parece que todo son ventajas ${ }^{108}$ cuando se trata del home-sharing frente al turismo tradicional; el servicio es mucho más cercano al tratarse de una relación de igual a igual; está personalizado ya que no existe una estructura corporativa detrás, lo que favorece el conocimiento mutuo y facilita la adaptación del producto o servicio a los gustos del consumidor a un precio mucho más bajo, al tiempo que crea la figura del ciudadano productor, que produce, consume e intercambia los roles de proveedor y cliente.

de ropa a la salida y entrada; limpieza de zonas comunes del edificio, servicio de asistencia técnica y mantenimiento para eventuales reparaciones. Por el contrario, la persona física que arrienda un bien inmueble de su titularidad sin prestar los servicios propios de la industria hotelera y sin local destinado a la actividad, ni personal contratado, obtendrá una renta calificada como rendimientos del capital inmobiliario por el IRPF (JIMÉNEZ NAVAS, M.M., “El régimen jurídico-fiscal del turismo en España”, en JIMÉNEZ CABALLERo, J.L., DE FUENTES RUIZ, P., SANZ DOMíNGUEZ, C., Turismo y sostenibilidad: V Jornadas de Investigación en Turismo, Sevilla, Universidad de Sevilla, 2012, pp. 445-462, pp. 456-457. También GARCíA CALVENTE, Y., Aspectos tributarios del turismo residencial, Barcelona, Bosch, 2007, pp. 35 y ss).

106 Puede consultarse el informe Conclusiones preliminares sobre los nuevos modelos de prestación de servicios y la economía colaborativa, marzo 2016, de la CNMC en https://docs.google.com/document/d/1n65MjUaTmRLuZCqTIlqyWvobVqreR-iAzsz1mhxy2yo/edit.

107 Avancar, estudio Tendencias del consumo colaborativo en España (2014), puede consultarse online en http://client.avancar.es/ newsletter/infograficoPAYL-enero14.pdf.

108 Información proporcionada por el portal online de ASCAV, Asociación Canaria de Alquiler Vacacional.

REALA, Nueva Época, - N. ${ }^{\circ}$, enero-junio 2016 - ISSN: 1989-8975 - DOI: 10.24965/reala.voi5.10350 
Sin embargo, por muy bien que le siente a la economía familiar este tipo de alquileres vacacionales, debemos mostrarnos escépticos en cuanto a su encuadre dentro de la economía colaborativa. Si tal y como hemos visto la economía colaborativa se fundamenta en el compartir entre iguales y en ofrecer una segunda oportunidad a aquello que no utilizamos, la esencia de esta nueva filosofía de vida se ve completamente diluida cuando se refiere al alojamiento colaborativo a través de las plataformas virtuales. En efecto, el nuevo fenómeno del alojamiento colaborativo comenzó siendo un servicio peer-to-peer, esto es, de igual a igual, sin intermediarios, creado por y para los usuarios que construían la oferta y generaban confianza en los diferentes alojamientos gracias a los comentarios que dejaban de cada hospedaje. Se hablaba, por ello, de servicios de hospitalidad. En 2003 aparecía la plataforma CouchSurfing ${ }^{109}$, una página web que nació sin ánimo de lucro, y que ponía en contacto a quienes prestaban su sofá -couch- a aquellos turistas que estaban de paso por su ciudad; se trataba de un servicio completamente gratuito para todas las partes. Sin embargo, ocho años después de comenzar a funcionar, esta página recibió una fuerte inyección económica, transformándose en una empresa que cobraba un porcentaje por pernocta a cada una de las partes implicadas, de ahí que se comenzara a hablar jocosamente de «Couchșurfing». Esto hizo que se pusiera en tela de juicio su carácter colaborativo.

En cuanto a la norteamericana AirBnb -Airbed and breakfast-, plataforma que intermedia en el alquiler turístico tanto de viviendas como de habitaciones, su éxito se basa en los propios principios que inspiran la economía colaborativa: la convivencia en comunidad. Esta plataforma conecta a quienes quieren obtener un rendimiento económico temporal por su vivienda habitual o por su segunda vivienda, con aquellos que buscan alternativas a los hoteles tradicionales. Su funcionamiento es sencillo y ahí radica parte de su éxito, dado que su página ya alberga más de 650.000 viviendas en todo el mundo, lo que ha convertido a esta empresa en un gigante cuyo valor en el mercado asciende a unos 23 millones de euros.

¿Cuál es, por tanto, el papel de esta plataforma en el alojamiento colaborativo que anuncia? El caso de AirBnb es significativo. Esta empresa gestiona una página web de contenidos en la que distintos particulares ofertan inmuebles para que, quienes lo deseen, alquilen por noche dichos espacios a cambio de una contraprestación. Su actividad es, por tanto, una loa a la economía colaborativa ya que, como ella misma recoge, es un mercado comunitario (market place) basado en la confianza, en el que se publican, descubren y reservan alojamientos únicos y privados en todo el mundo, desde un ordenador, tableta o teléfono móvil, de acuerdo a lo que reza su lema: como en casa donde vayas. Jurídicamente, los market place son simples «albergadores de datos» que sirven como «punto de encuentro» de oferta y demanda, lo que supone que estamos ante servicios de alojamiento que suministran servicios a la sociedad de la información ${ }^{110}$. Se establece, por tanto, una relación triangular en la que el anfitrión -propietario de la viviendaoferta servicios de alojamiento vacacional al pernoctante -turista- a través de la página web de AirBnb.

Ahora bien, si bien AirBnb presume de ser la primera plataforma de alojamiento colaborativo basada en la confianza, no se trata en ningún caso de un ejemplo de economía peer-to-peer (p2p) o de igual a igual ya que su labor ha pasado de ser una mera gestora de contenidos a obtener un rendimiento directo por cada alquiler que gestiona. Así, la contraprestación que se paga ya no es sólo por la cesión de uso, sino también por los servicios ofertados por esta plataforma; los pernoctantes pagan una cantidad por noche a los anfitriones y AirBnb cobra un porcentaje a ambas partes -entre un 6 y un $12 \%$ al pernoctante y un $3 \%$ al anfitrión-. De este modo, opera como si de una gran agencia de viajes online ${ }^{111}$ se tratase, pero sin estar sometida a la regulación administrativa correspondiente y sin las garantías necesarias ${ }^{112}$.

109 La página CouchSurfing fue creada por un estudiante, Casey Fenton, que buscaba alojamiento en casa de otros estudiantes en Islandia; tras enviar unos 1500 emails recibió medio centenar de respuestas; una de ellas le decía que le prestaban su sofá durante algunas noches. A día de hoy cuenta con más de 7 millones de perfiles registrados en más de cien mil ciudades, aunque se ha convertido más en una suerte de red social que en una plataforma de turismo colaborativo.

110 FERnÁndeZ FLoRES, F., “La naturaleza jurídica de los marketplace”, p. 13, disponible online en la página web de la Federació d'Hostaleria de Lleida: http://www.horecalleida.es/wp-content/uploads/Naturaleza-Juridica-de-los-marketplaces.pdf.

111 Ya es una práctica habitual que en el mercado turístico medien empresas que operen a través de Internet. Sin embargo, los problemas que este tipo de oferta y venta a distancia han generado, han derivado de un vacío normativo que no preveía las obligaciones y responsabilidades de este tipo de agentes mediadores. Las CCAA venían acogiendo a este tipo de agentes dentro de los empresarios cuya actividad ha de regularse por las leyes singulares de venta a distancia, ordenación del comercio, contratación electrónica o sin establecimiento mercantil específico (Directiva 2000/31/CE, de 8 de junio, relativa a determinados aspectos jurídicos de los servicios de la sociedad de la información, en particular del comercio electrónico en el mercado interior y la Ley 34/2002, de 11 de junio, de servicios de la sociedad de la información y comercio electrónico. Murcia cuenta con el Decreto 100/2007, de 25 de mayo, por el que se regulan las agencias de viaje y las centrales de reserva, estableciendo en su art. 3 que la organización, intermediación y comercialización de servicios turísticos a distancia a título oneroso, sólo podrá hacerse por agencias de viaje o centrales de reserva debidamente autorizadas. En el mismo sentido, el Decreto 60/2007, de 24 de mayo, por el que se aprueba el Reglamento de las Empresas de Intermediación Turística de Asturias (arts. 32 y 33). Véase FERNÁNDEZ RoDRíGUEZ, C., Derecho Administrativo Turístico, op. cit., pp. 221-222.

112 Recordemos que en materia de servicios turístico de intermediación y complementarios, nos encontramos con un conjunto de actividades empresariales de todo tipo ligadas al turismo desde el punto de vista de los servicios conexos con la oferta turística pro- 
Estas labores de intermediación a cambio de precio se separan claramente de la esencia de la economía colaborativa, al dejar de ser una transacción entre iguales ${ }^{113}$, pasando a formar parte de la economía convencional. Como sabemos, la economía colaborativa pone frente a frente al productor y al consumidor, entrando en juego el valor del trabajo de los demás: el trato directo genera relaciones de cooperación, existiendo un conocimiento y comprensión mutuos de las necesidades y problemas que pueden afectarles y una solidaridad con los obstáculos, porque son entendidos como comunes ${ }^{114}$, mientras que en la economía convencional existen intermediarios. Esta plataforma virtual es un ejemplo de alteración de la esencia de la economía colaborativa al tratarse de un verdadero modelo de negocio, manifestación del capitalismo más puro ${ }^{115}$. Por esta razón, queda patente que la actividad que AirBnb desarrolla está completamente alejada de los dictados de la economía colaborativa. Se trata, al fin y al cabo, de un intermediador que opera en la Red y que recibe una contraprestación por sus servicios.

De este modo, quienes ofertan inmuebles a través de estas plataformas a cambio de una contraprestación han hecho del home-sharing un lucrativo negocio al margen de la legalidad. ¿Qué tiene de colaborativo el hecho de que se alquilen segundas residencias a través de AirBnb o de cualquier otra plataforma online? La cesión de uso de la residencia no habitual a través de estas páginas web no convierte el alquiler en colaborativo, ni tampoco le otorga apariencia de legalidad, a pesar de que muchos propietarios y propietarias así lo crean. Así que, por mucho que nos pese, alquilar no es compartir y decir que estas plataformas virtuales promueven la economía colaborativa es un mero eufemismo que en demasiadas ocasiones no persigue sino justificar el incumplimiento de obligaciones legales que cualquier actividad de esta índole, como las equivalentes a las mismas, han de satisfacer en beneficio de ciertos valores públicos, desde las fiscales a las de orden público.

\section{BIBLIOGRAFÍA}

Agyeman, J., MCLARen, D., SChaefer-Borrego, A., "Sharing cities", Friends of the Earth. BELK, R., "Sharing”, Journal of Consumer Research, vol. 36, n. ${ }^{\circ}$ 5, 2010, pp. 715-734. DOI: dx.doi.org/10.1086/612649. BERMEJO VERA, J., Derecho Administrativo, parte especial, Madrid, Civitas, 2009.

BÁdenAs CARPIO, J.M., "El contrato de hospedaje", en Petit LAVAll (Coord.), M.T., Lecciones de Derecho del Turismo, Valencia, Tirant lo Blanch, 2000, pp. 283-300.

BoIX PALOP, A., “De McDonald's a Google: la ley ante la tercera revolución productiva”, Teoría y Derecho: Revista de Pensamiento Jurídico, n. ${ }^{\circ} 1,2007$, pp. 124-146.

BouAzZA ARIÑo, O., La planificación territorial en Gran Bretaña. Especial referencia al sector turístico, Cizur Menor, Civitas Thomson-Reuters, 2009.

- "El turismo", en CANo CAMPos, T., Lecciones y materiales para el estudio del Derecho Administrativo, tomo VIII, Los sectores regulados, vol. II, Madrid, lustel, 2009, pp. 153-182.

BLANQUER CRIADO, D., Derecho del Turismo, Valencia, Tirant lo Blanch, 1999.

BlAsco ESTEVE, A., "Planificación y gestión del territorio turístico de las Islas Baleares", en MELGOSA ARCos, F.J. (Ed.), Derecho y turismo, Salamanca, Ediciones Universidad de Salamanca, 2004, pp. 385-436.

BOTSMAN, R., ROGERS, R., What's mine is yours: the rise of collaborative consumption, Nueva York, Harpers Collins Publishers, 2010.

\footnotetext{
piamente dicha. En el mismo destaca la actividad de intermediación turística por excelencia, sobre la que ha sido particularmente intensa la atención prestada por el legislador autonómico, como es la que realizan las empresas que actúan como agencias de viajes. (BERMEJo VerA, Derecho Administrativo. Parte especial, op. cit., p. 1019. También BlANQuER CRIAdo, D., Derecho del Turismo, Valencia, Tirant lo Blanch, 1999, pp. 311 y ss). Esta mediación turística es la actividad consistente en la intermediación entre el usuario y el ofertante del servicio turístico, así como la organización del producto turístico, que se canaliza básicamente a través de los establecimientos turísticos denominados agencias de viajes, que despliegan su actividad mediadora sometidas a determinadas exigencias de índole administrativa, sin perjuicio de otras exigencias de de diferentes naturaleza. No obstante, junto a ellas, es posible encontrar otro tipo de empresas de intermediación turística, como son los organizadores profesionales de congresos, centrales de reservas, empresas de comercialización turística, etc. que han de someterse en cada caso a las exigencias administrativas de mediación en el mercado turístico (FERNÁNDEZ RoDRíGUEZ, C., Derecho Administrativo Turístico, op. cit., p. 212). En este sentido, tienen la consideración de agencias de viajes las empresas cuya actividad profesional y comercial es el ejercicio de actividades de mediación y/o de organización de servicios turísticos (CoRCHERo, M., Derecho del Turismo, Madrid, Iustel, 2008, p. 49).

113 En el caso de estas plataformas gestionadas, tras analizar 300.000 ofertas, sólo un $7 \%$ se corresponden con viviendas de intercambio y el restante $93 \%$ se ofrecen a través de contraprestación, además de que la mitad de la oferta pertenece a empresas y a propietarios con más de una vivienda. Datos disponibles en el informe "Impactos sociales y económicos sobre los destinos españoles derivados del exponencial aumento del alquiler de viviendas turísticas de corta duración, impulsado por los nuevos modelos y canales de comercialización P2P”, de Exceltur (junio, 2015); puede consultarse online en http://epoo.epimg.net/descargables/2015/06/25/04d5042196ea7da17531da405704a3eb.pdf.

114 Conill, J., CARdenas, A., CAStells, M., Servon, L., SviAtlanA, H., Otra vida es posible. Prácticas económicas alternativas durante la crisis, op. cit., pp. 155-156.

115 GinÈs i FABRELLAS, A., GÁLVEZ DURÁN, S., "Sharing economy vs. uber economy y las fronteras del Derecho del Trabajo: la (des)protección de los trabajadores en el nuevo entorno digital”, InDret, Revista para el análisis del Derecho, n. 1, 2016 , pp. 1-44, pp. 5-6.
}

REALA, Nueva Época, - N. ${ }^{\circ}$ 5, enero-junio 2016 - ISSN: 1989-8975 - DOI: 10.24965/reala.voi5.10350 
CAMPUZANO TOMÉ, H., "El alquiler de viviendas de uso turístico a partir de la Ley 4/2013: la necesaria interpretación conjunta de la LAU y de la legislación turística autonómica”, Revista Crítica de Derecho Inmobiliario, n. ${ }^{\circ} 749$, 2015, pp. 1199-1246.

CANTOS MARTín, R., “La planificación turística y los entes públicos de gestión en el desarrollo de las grandes ciudades: Ios modelos de Barcelona y Londres”, Ciudad y Territorio. Estudios Territoriales, n. ${ }^{\circ}$ 182, 2014, pp. 649-670.

CAÑIGUERAl BAGó, A., Vivir mejor con menos. Descubre las ventajas de la nueva economía colaborativa, Barcelona, Conecta, 2014.

CARDOSO, G., JACOBETTY, P., “Navegando por la crisis: culturas de pertenencia y cambio social en red”, en CARDOSO, G. (Ed.), Sociología de las pantallas, Editorial UOC, 2014.

Carrasco Perera, Á., "Comentarios al proyecto de ley de reforma de los arrendamientos de viviendas, CESCO, Revista de Derecho de Consumo, n. ${ }^{\circ}$, 2012, pp. 118-134.

Conill, J., Cardenas, A., Castells, M., Servon, L., Sviatlana H., Otra vida es posible. Prácticas económicas alternativas durante la crisis, Barcelona, Editorial UOC, 2012.

CORCHERO, M., Derecho del Turismo, Madrid, lustel, 2008.

CORTINA VALLACANERA, J., "Sistema actual de los instrumentos de intervención ambiental en la Comunidad Valenciana", Práctica urbanística, n. ${ }^{\circ} 117,2010$, pp. 12-29.

Cuscó Puigdellívol, E., Font Garolera, J., "Nuevas formas de alojamiento turístico: comercialización, localización y regulación de las viviendas de uso turístico en Cataluña”, BibliozW, Revista Bibliográfica de Geografía y Ciencias Sociales, n. ${ }^{\circ} 1134,2015$, pp. 1-17.

DE LA IGLESIA PRADOS, E., “La reforma en la regulación del contrato de arrendamiento urbano de vivienda de junio de 2013", Actualidad Civil, n. ${ }^{\circ} 11,2013$, pp. 1-12.

DOMÉNECH PASCUAL, G., "La regulación de la economía colaborativa (Uber contra el taxi), Revista CEF Legal, n. ${ }^{\circ} 175-176,2015$, pp. 61-104.

DeVAuX, C., L'habitat participatif: De l'initiative habitante à l'action publique, Paris, Presses Universitaires Rennes, 2015.

FERNÁNDEZ FLORES, R., “La naturaleza jurídica de los market-place”, disponible online en la página web de la Federació d’Hostaleria de Lleida: http://www.horecalleida.es/wp-content/uploads/Naturaleza-Juridica-delos-marketplaces.pdf.

FERnÁndez RodríGuez, C., Derecho Administrativo Turístico, Madrid, Marcial Pons, 2013.

FERRARY, N., "Les nouvelles formes de tourisme collaboratif: una demande en pleine expansion", Annales des Mines. Réalités industrielles, n. ${ }^{\circ}$ 3, 2015, pp. 50-53.

FRANCH FLUXÁ, J. y RIBAS CONRADO, J.F., "El alquiler de viviendas para uso vacacional. Perspectiva actual, problemas y propuestas legales", Estudios Turísticos, n. ${ }^{\circ} 195,2013$, pp. 33-57.

FUENTES-LOJO RiUS, A., "Prohibición de explotación turística de la vivienda por ser contraria a la convivencia

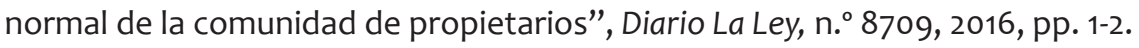

GANSKY, L., La malla, el futuro de los negocios es compartir, Barcelona, Ediciones Gestión 2000, 2011.

GARCía CALVENTE, Y., Aspectos tributarios del turismo residencial, Barcelona, Bosch, 2007.

GARCía SAURA, P.J., Desarrollo sostenible y turismo. Análisis del régimen jurídico medio ambiental de la legislación turística española, Madrid, Thomson-Aranzadi, 2007, p. 89.

GinÈs i FABRELlAS, A., GÁlvez DuRÁN, S., "Sharing economy vs. uber economy y las fronteras del Derecho del Trabajo: la (des)protección de los trabajadores en el nuevo entorno digital”, InDret, Revista para el análisis del Derecho, n. ${ }^{\circ} 1,2016$, pp. 1-44.

GonzÁlez CARRASCO, C., "El nuevo régimen de los arrendamientos de vivienda tras la ley de medidas de flexibilización y fomento del mercado del alquiler”, Revista de Derecho de Consumo, n. 6, 2013, pp. 170-190.

GUILLÉn CARAmÉs, J., “Algunos aspectos de la protección jurídica del turista”, Revista Española de Derecho Administrativo, n. ${ }^{\circ} 115,2002$, pp. 357-380.

GUILLÉN NAVARRo, N.A., "La vivienda de uso turístico y su incidencia en el panorama normativo español”, Revista Aragonesa de Administración Pública, n. ${ }^{\circ}$ 45-46, 2015, pp. 101-144.

GuIllÉn NAVARRo, N.A., IÑIGUEZ BerRozPE, T., "Las viviendas de uso turístico en el nuevo entorno p2p. Retos sociojurídicos para el consumo colaborativo en el alojamiento turístico", Estudios Turísticos, n. ${ }^{\circ}$ 205, 2015, pp. 9-34.

Heide, D., Peters, K.B.M., “AirBnb als hulpmiddel voor spreiding van toerisme in Amsterdam?”, Vrijetijdstudies, n. ${ }^{\circ}$ 2, 2015, pp. 9-22.

JefFERSON-JONES, J., "AirBnb and the Housing Segment of the Modern "Sharing Economy": Are Short-Term Rental Restrictions an Unconstitutional Taking?”, Hastings Constitutional Law Quarterly, n. ${ }^{\circ}$ 3, pp. 457-576.

JIMÉNEZ NAVAS, M.M., “El régimen jurídico-fiscal del turismo en España”, en JimÉnEz CABALLERO, J.L., DE FUENTES Ruiz, P., SAnz Domínguez, C., Turismo y sostenibilidad: V Jornadas de Investigación en Turismo, Sevilla, Universidad de Sevilla, 2012, pp. 445-462. 
JIMÉNEZ SOTO, I., "Ordenación de los servicios turísticos: competencias administrativas y unidad de mercado", ponencia presentada en el XXI Congreso Italo-Español de Profesores de Derecho Administrativo, celebrado en Alicante los días 26, 27 y 28 de mayo de 2016.

KALLIS, G., "El futuro dialéctico del decrecimiento: ¿ficción distópica o proyecto emancipador?”, Revista de Economía Crítica, n. ${ }^{\circ} 19,2015$, pp. 21-33.

KASSAN J., ORSI, J., "The legal landscape of the sharing economy", Journal of Environmental and Litigation, n. ${ }^{\circ} 27$, 2012, pp. 1-20.

KELLY, K., "Better than owning", The Technium, 2009.

LATOUCHE, S., La apuesta por el decrecimiento ¿Cómo salir del imaginario dominante?, Barcelona, Icaria Antrazyt, 2006.

LefEBVRE, N., "Destination et expériences: l'adaptation de l'offre touristique de Paris aux nouvelles attentes", Annales des Mines. Réalités industrielles, n. ${ }^{\circ}$ 3, 2015, pp. 58-62.

LÓPEZ BONILLA, J.M, LÓPEZ BONILLA, L.M., "La capacidad de carga turística: revisión crítica de un instrumento de medida de sostenibilidad”, El periplo sustentable, n. ${ }^{\circ} 15,2008$, 123-150. DOI: 10.21854/eps.voi15.938.

MARTínez CAÑELLAS, A., "La cesión del uso de la vivienda a no residentes: contrato de alojamiento (de estancias turísticas) en viviendas y el contrato de arrendamiento de temporada, conforme a la Ley del Turismo de las Islas Baleares tras la reforma de la Ley de Arrendamientos Urbanos" Boletín de la Academia de Jurisprudencia y Legislación de las Illes Balears, n. ${ }^{\circ}$ 15, 2014, pp. 151-176.

MARZAL RAGA, R., "Unidad de mercado y clasificación hotelera", comunicación presentada en el XXI Congreso Italo-Español de Profesores de Derecho Administrativo, celebrado en Alicante los días 26, 27 y 28 de mayo de 2016.

MÉNDEZ, R., "Redes de colaboración y economía alternativa para la resiliencia urbana: una agenda de investigación”, Revista Bibliográfica de Geografía y Ciencias Sociales, n. 1139, 2015, pp. 1-24.

MERINO MOLINS, V., "Los instrumentos de intervención ambiental en la Ley 6/2014, de 25 de julio, de Prevención, Calidad y Control Ambiental de Actividades de la Comunidad Valenciana (II). La licencia ambiental y otros medios de intervención", Consultor de los ayuntamientos y los juzgados, n. ${ }^{\circ} 7,2015$, pp. 830-838.

NASARRE AZNAR, S., "La eficacia de la Ley 4/2013, de reforma de los arrendamientos urbanos, para aumentar la vivienda en alquiler en un contexto europeo", Revista Crítica de Derecho Inmobiliario, n. ${ }^{\circ} 747$, 2015, pp. 205-249.

NúÑEZ IGLESIAS, Á., "Tipología de los contratos de alojamiento extrahotelero (I)", Actualidad Civil n. 12, 2010, pp. 1-20.

OSKAM, J., BOSWIJK, A., "AirBnb: the future of networked hospitality businesses", Journal of Tourism Futures, n. ${ }^{\circ}$ 1, 2016, pp. 22-42. DOI: 10.1108/jtf-11-2015-0048.

Peñarrubia IzA, J., Moralo IzA, V.M., "Promoción y ordenación del turismo de congresos. Reflexiones en torno al OPC", en MelGoSA ARCOS, F.J., (Coord.), Derecho y Turismo, Salamanca, Ediciones Universidad de Salamanca, 2004, pp. 271-288.

PÉREZ FERNÁNDEZ, J.M., Régimen jurídico del turismo rural, Madrid, FITUR, 2001.

PÉREZ GUERRA, R., "La intervención administrativa en el sector turístico español. La política turística", Revista Aragonesa de Administración Pública, n. ${ }^{\circ}$ 43-44, 2014, pp. 396-413.

PÉRINET-MARQUET, H., "Accès au logement et urbanisme rénové. Loi ALUR du 24 mars 2014", Semaine juridique, n. ${ }^{\circ} 15,2014$, pp. 709-712.

Quattrone, G., Proserpio, D., Quercia, D., CAPRA, L.,Musolesi, M., "Who benefits from the "Sharing» Economy of AirBnb?", International World Wide Web Conference, n. ${ }^{\circ} 16,2016$, pp. 1385-1394.

RIFKING, J., La civilización empática. La carrera hacia una conciencia global en un mundo en crisis, Barcelona, Paidós, 2010.

ROMÁN MÁRQUEZ, A., "Las viviendas particulares dedicadas a la actividad de alojamiento turístico. Su exclusión de la Ley de arrendamientos urbanos", Revista Internacional de Doctrina y Jurisprudencia, n. ${ }^{\circ}$ 1, 2014, pp. 1-24.

RodríGUeZ-PIÑERo Bravo-FerReR, M., "La intervención administrativa en la empresa hotelera", en Primer Congreso Italo-Español de Profesores de Derecho Administrativo, Ministerio de Información y Turismo, Madrid, 1970.

TODolí SIGNES, A., “El Impacto de la 'Uber economy' en las relaciones laborales: los efectos de las plataformas virtuales en el contrato de trabajo", Iuslabor, n. ${ }^{\circ}$ 3, 2015 pp. 1-25.

VARA ARRIBAS, G., StelBLE, B., De Bondt, Informe "Cost of non-Europe in the sharing economy: legal aspectsn (PE558.777) a solicitud del Impact Assessment Unit of the Directorate for Impact Assessment study under no. and is republished here by EIPA with the kind permission of the European Parliament".

VERDERA IzQUIERDO, B., "El arrendamiento de temporada frente a las estancias turísticas en viviendas", El consultor Inmobiliario, n. ${ }^{\circ} 107,2009$, pp. 1-17.

— “La problemática del turismo residencial”, Diario La Ley, n. 7297, 2009, pp. 1-17.

REALA, Nueva Época, - N. ${ }^{\circ}$ 5, enero-junio 2016 - ISSN: 1989-8975 - DOI: 10.24965/reala.voi5.10350 
Villar Palasí, J.L., Prólogo en Fernández Álvarez, J., Curso de Derecho Administrativo Turístico I, Editora Nacional, Madrid, 1970.

VÖLKER, B., FLAP, H., "Sixteen million neighbors: a multilevel study of the role of neighbors in the personal networks of the Dutch" Urban Affairs Review, vol. 43, n. ${ }^{\circ}$ 2, 2007, pp. 256-284gavin james.

Zelizer, V., Economic Lives: How Culture Shapes the Economy, Princeton University Press, 2010. DOI: $10.1515 / 9781400836253$. 